\title{
Development of Virus-Like Particle Technology from Small Highly Symmetric to Large Complex Virus-Like Particle Structures
}

\author{
Peter Pushko $^{a} \quad$ Paul Pumpens ${ }^{b, c}$ Elmars Grens ${ }^{b}$ \\ a Medigen Inc., Frederick, Md., USA; 'b Latvian Biomedical Research and Study Centre, and ' Faculty of Biology, \\ University of Latvia, Riga, Latvia
}

\section{Key Words}

Virus-like particles · Three-dimensional structure - Vaccines .

Drug delivery · Biotechnology

\begin{abstract}
Virus-like particle (VLP) technology is a promising approach for the construction of novel vaccines, diagnostic tools, and gene therapy vectors. Initially, VLPs were primarily derived from non-enveloped icosahedral or helical viruses and proved to be viable vaccine candidates due to their effective presentation of epitopes in a native conformation. VLP technology has also been used to prepare chimeric VLPs decorated with genetically fused or chemically coupled epitope stretches selected from immunologically defined target proteins. However, structural constraints associated with the rigid geometrical architecture of icosahedral or helical VLPs pose challenges for the expression and presentation of large epitopes. Complex VLPs derived from non-symmetric enveloped viruses are increasingly being used to incorporate large epitopes and even full-length foreign proteins. Pleomorphic VLPs derived from influenza or other enveloped viruses can accommodate multiple full-length and/or chimeric proteins that can be rationally designed for multifunctional purposes, including multivalent vaccines. Therefore, a
\end{abstract}

second generation of VLP carriers is represented by complex particles reconstructed from natural or chimeric structural proteins derived from complex enveloped viruses. Further development of safe and efficient VLP nanotechnology may require a rational combination of both approaches.

Copyright $\odot 2013$ S. Karger AG, Basel

\section{VLP Concept and Its Evolution from Simple Icosahedral to Complex Enveloped Particles}

Recombinant virus-like particles (VLPs) are nanodimensional structures that (1) are built from one or several viral structural constituents in the form of recombinant proteins synthesized in efficient homologous or primarily heterologous expression systems (bacteria, yeast, or eukaryotic cell culture); (3) are identical or closely related by their three-dimensional architecture and immunochemical characteristics to naturally occurring viral structures, and (3) lack genomes or infectivity [1-5]. VLPs can be formed from nucleocapsid or envelope proteins alone and the term VLP will be used here to describe any multimolecular structure formed by viral capsid and/ or envelope proteins or by capsid and envelope combinations. The term non-chimeric VLPs is used for particles

\section{KARGER}

E-Mail karger@karger.com

www.karger.com/int (c) 2013 S. Karger AG, Basel

0300-5526/13/0563-0141\$38.00/0
Paul Pumpens

Latvian Biomedical Research and Study Centre

Ratsupites 1

LV-1067 Riga (Latvia)

E-Mail paul@biomed.lu.lv 
that are constructed from the original native non-modified viral proteins, whereas VLPs are defined as chimeric when the original structural proteins are covalently modified by the addition or substitution of foreign polypeptide stretches with functional properties, such as immunological epitopes or cell-targeting or encapsidation signals [5]. Covalent integration into chimeric VLPs can be achieved either by the expression of VLP monomer genes containing the appropriate insertions encoding the desired protein stretches $[1-3,5]$ or by the chemical coupling of peptides, proteins, or other molecules to VLPs [6]. Complex VLPs carrying full-length foreign proteins are defined here as hybrids.

Chimeric and/or hybrid VLPs target three main functional applications: (1) presentation of foreign epitopes leading to novel immunological content and subsequently to the creation of novel vaccines; (2) encapsidation of various therapeutic or diagnostic agents, such as nucleic acids as adjuvants for vaccines or gene therapy, proteins or mRNAs for diagnostic or therapeutic purposes, or lowmolecular-weight drugs to be delivered to specific cells, and (3) specific targeting of desired organs, tissues, or cells.

Historically, the first two VLPs were derived from hepatitis B virus (HBV) and expressed in Escherichia coli and Saccharomyces cerevisiae during the mid-1980s. These VLPs were hepatitis B core (HBc) [7-9] and surface (HBs) [10] particles, which possessed icosahedral and octahedral symmetry, respectively [for a detailed review, see 11]. Later, the first representatives of VLPs derived from small RNA bacteriophages, non-enveloped bacterial viruses, were described [12-16]. The first rod-shaped chimeric VLPs with helical symmetry were derived at the same time from tobacco mosaic virus [17]. Enveloped VLPs from complex enveloped viruses, such as influenza viruses or the Ebola virus, were only introduced after more than 20 years of research [18-20].

In this review, we illustrate the evolution of the VLP concept from highly ordered symmetric VLPs to large complex VLPs derived from enveloped viruses. In most cases, symmetric VLPs are structurally well characterized by high-resolution techniques (protein X-ray crystallography and cryo-electron microscopy), whereas complex enveloped VLPs are often less structurally characterized. Figure 1 presents images of crystal structures of non-enveloped icosahedral viruses and experimental photomicrographs of complex enveloped viruses that have been used for the preparation of VLPs. Table 1 summarizes data on the various VLPs and demonstrates that almost all viral families have contributed to the development of VLP technology.

\section{Non-Enveloped Icosahedral and Helical VLPs}

\section{Native Non-Chimeric VLPs}

Non-enveloped native VLPs composed of unmodified viral proteins have been used as vaccines and configured as epitope display carriers (table 1). Recombinant icosahedral and, to lesser extent, helical VLP structures provide exceptionally effective environments for a high-density symmetric display of foreign oligopeptides, whereas three-dimensional maps of VLPs allow for the rational design of sites for epitope insertion. The regular repetitive pattern and correct conformation of the initial and inserted epitopes of symmetric VLPs have been recognized as critical features for the induction of a strong immunological response and for their potential use as highly efficient vaccines [for reviews, see 5, 6, 11, 21-28].

The interest in rationally designed manipulations of chimeric VLPs has been reinforced by the determination of the structures of many viral capsids by protein X-ray crystallography. The upper part of figure 1 shows crystal structures of representative icosahedral VLPs. As is evident, VLPs have been derived from all classes of viral genomes, i.e., double- and single-stranded DNA and RNA. Thus far, most VLPs have been derived from viruses with single-stranded RNA genomes of positive polarity lacking a DNA intermediate. Complex VLPs were recently constructed from large enveloped negative-strand RNA viruses such as influenza viruses and Ebola virus (see the section 'Complex VLPs derived from enveloped viruses' below).

As indicated in table 1, some icosahedral and helical VLPs have been used as vaccines in their native, non-chimeric form without the introduction of foreign sequences (for references, see table 1). For example, the HBs antigen that represents $22-\mathrm{nm}$ particles produced in yeast has been a successful HBV vaccine since 1986. Another structural HBV protein, a nucleocapsid or $\mathrm{HBc}$ particle, is being tested as a component of a therapeutic HBV vaccine (table 1). Yet another example of a native, non-chimeric VLP vaccine are human papillomavirus (HPV) VLPs produced in yeast or baculovirus expression systems, which went onto the market in 2006 and 2007, respectively, as vaccines against cervical cancer. Norwalk virus and rotavirus VLPs against the major etiologic agents of epidemic gastroenteritis in humans are currently in clinical trials.

Animal circovirus and parvovirus VLP vaccines have been designed against infections in pigs and dogs (table 1). Other animal vaccines that are based on non-modified native VLPs have been prepared against calicivirus 


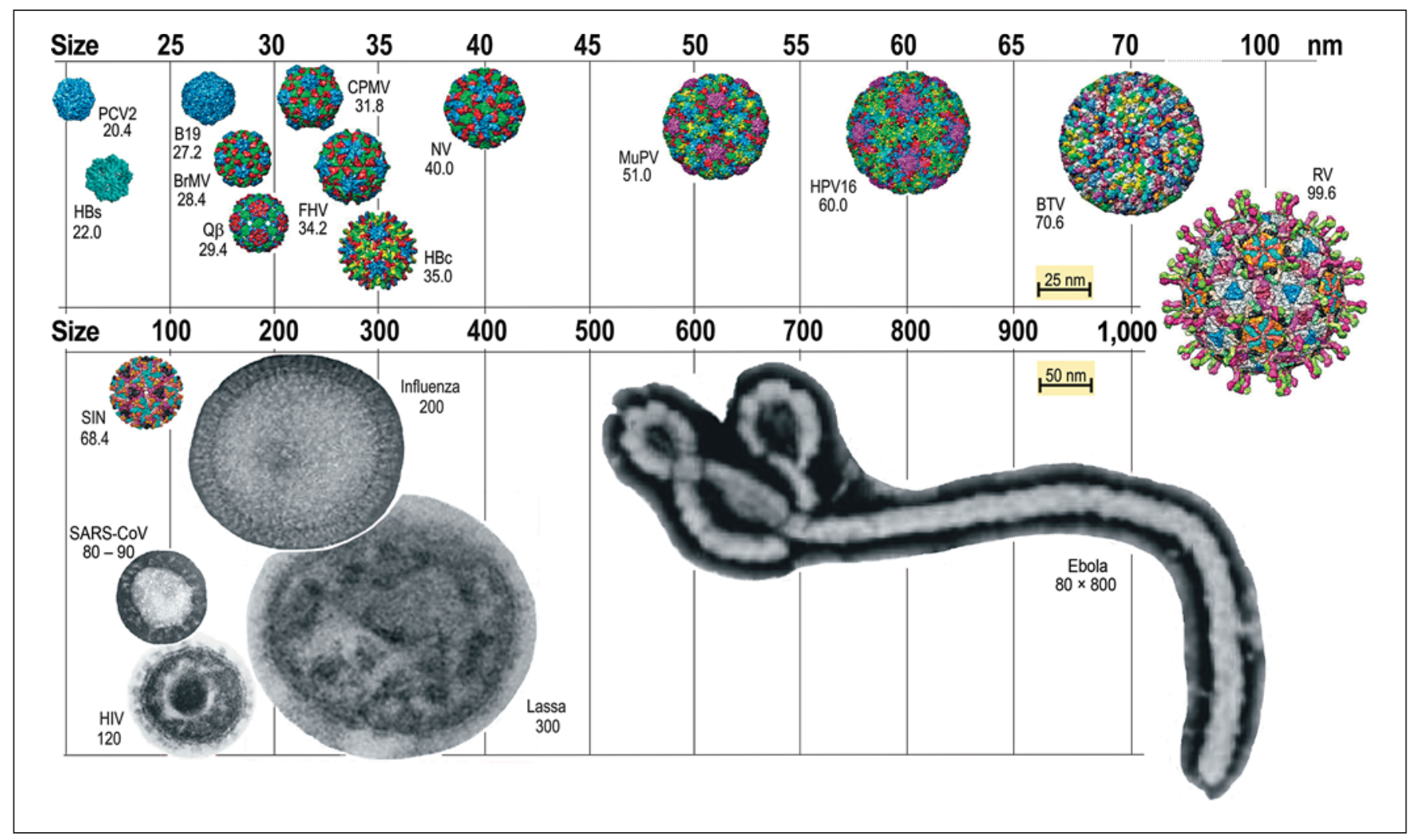

Fig. 1. Size-scaled presentation of the crystal structures of nonenveloped icosahedral viruses and experimental photomicrographs of the complex enveloped viruses that have been used for the preparation of VLPs. Three-dimensional models of structur- ally resolved particles are from the VIPERdb database [400, 401]. The structure of the HBs particle with octagonal symmetry is from Gilbert et al. [402]. Photomicrographs of enveloped viruses are from publicly available resources. For abbreviations, see table 1 .
(RHDV), papillomavirus (BPV and CRPV), reovirus (BTV), and birnavirus (AHSV) infections.

\section{Chimeric VLPs}

Table 1 lists the published chimeric VLPs (including hybrid VLPs) that have been prepared by either gene fusion or chemical coupling of epitope peptides to the VLP surface, with an emphasis on vaccine and drug delivery applications.

The earliest chimeric structures, which appeared during the mid-1980s, were either based on tobacco mosaic virus [17] or derived from HBs protein $[29,30]$. The development of the HBs protein has recently resulted in the first successful phase III clinical trial of a chimeric VLP vaccine, specifically the RTS,S vaccine against malaria $[31,32]$. Among icosahedral VLPs, which appeared at the same time in the 1980s, HBc and VLPs derived from RNA phages have often been used as scaffolds for the construction of both prophylactic and therapeutic vaccine candi- dates, which are in clinical trials. For example, singlestranded RNA phages have been extensively used for the development of therapeutic vaccines by attaching genetically fused and chemically coupled epitopes (for references, see table 1).

Among other icosahedra that have advanced to chimeric VLPs, capsids from parvoviruses (B19, PPV, and $\mathrm{CPV})$, comoviruses (CPMV), nodaviruses (FHV), polyomaviruses (MuPV and $\mathrm{HaPV}$ ), and papillomaviruses (HPV and BPV) have proved to be sufficiently flexible to retain the ability to self-assemble after genetic fusion with foreign peptides. CMV, a representative of cucumoviruses, has demonstrated the unique ability to remain replication-competent and to produce progeny of chimeric viruses carrying foreign insertions. Bromoviruses, along with the CPMV [for a review, see 33], have formed a niche of nanotechnological materials involved mostly in a variety of packaging protocols using BrMV and CCMV VLPs [for a review, see 34,35 ]. 


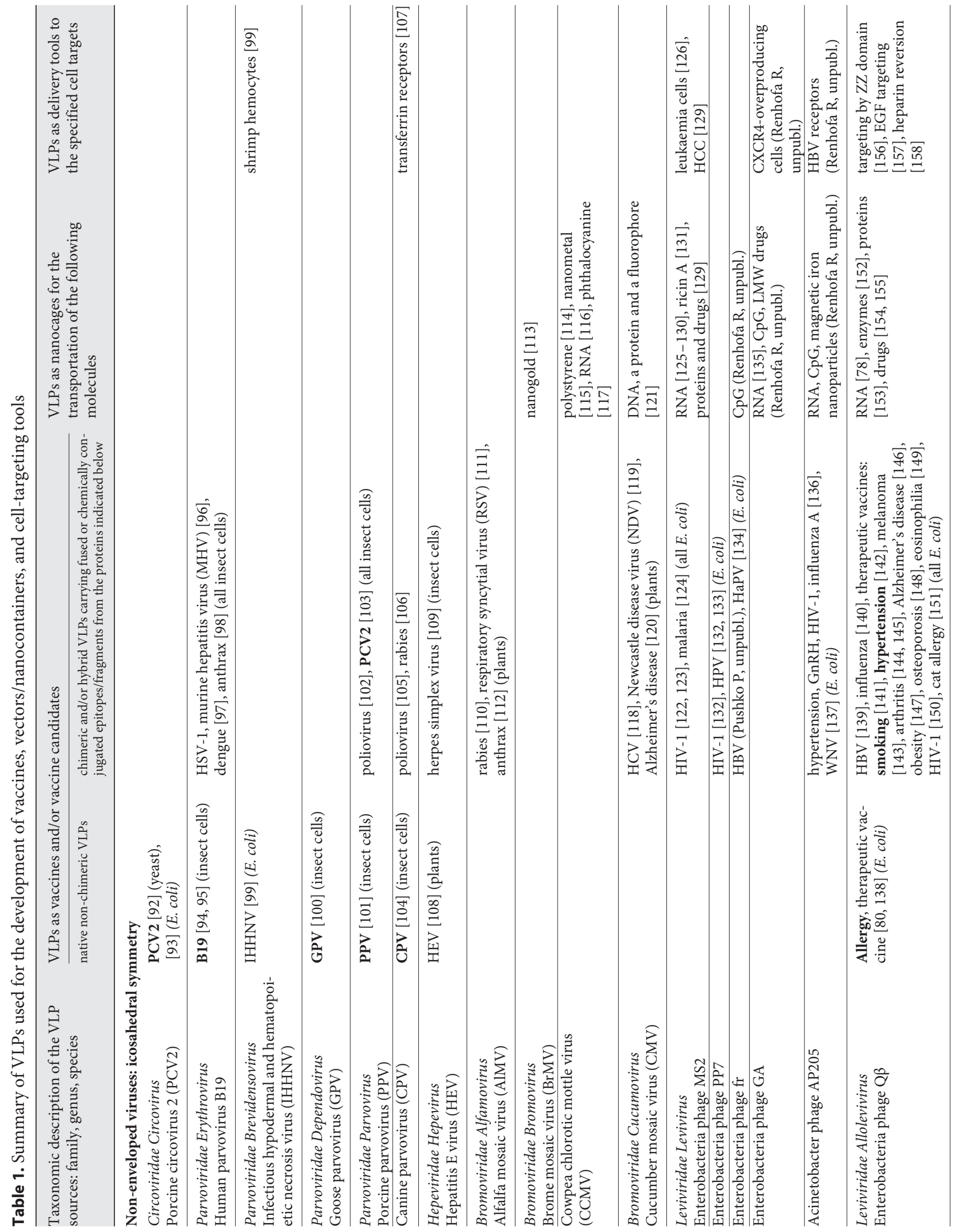




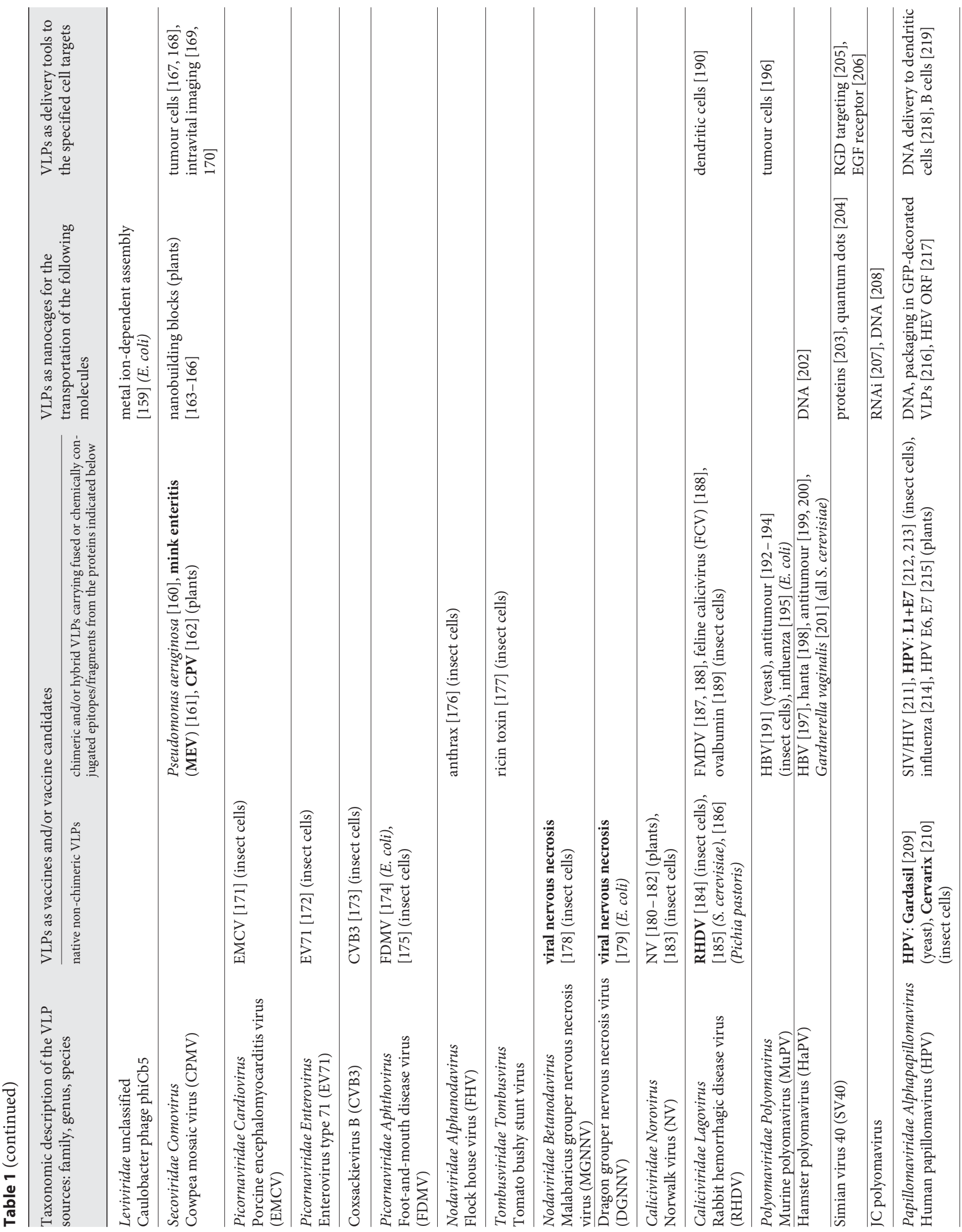




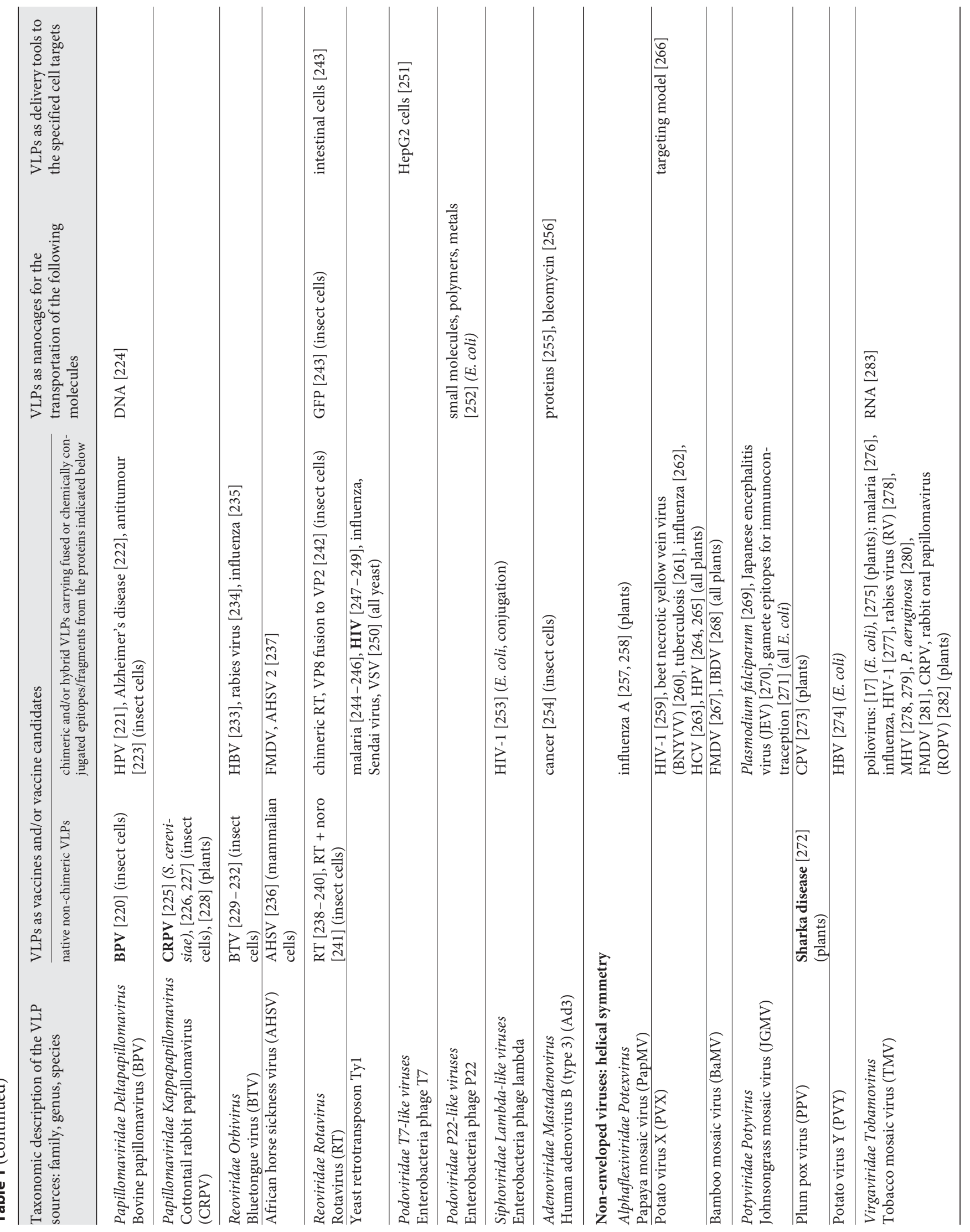




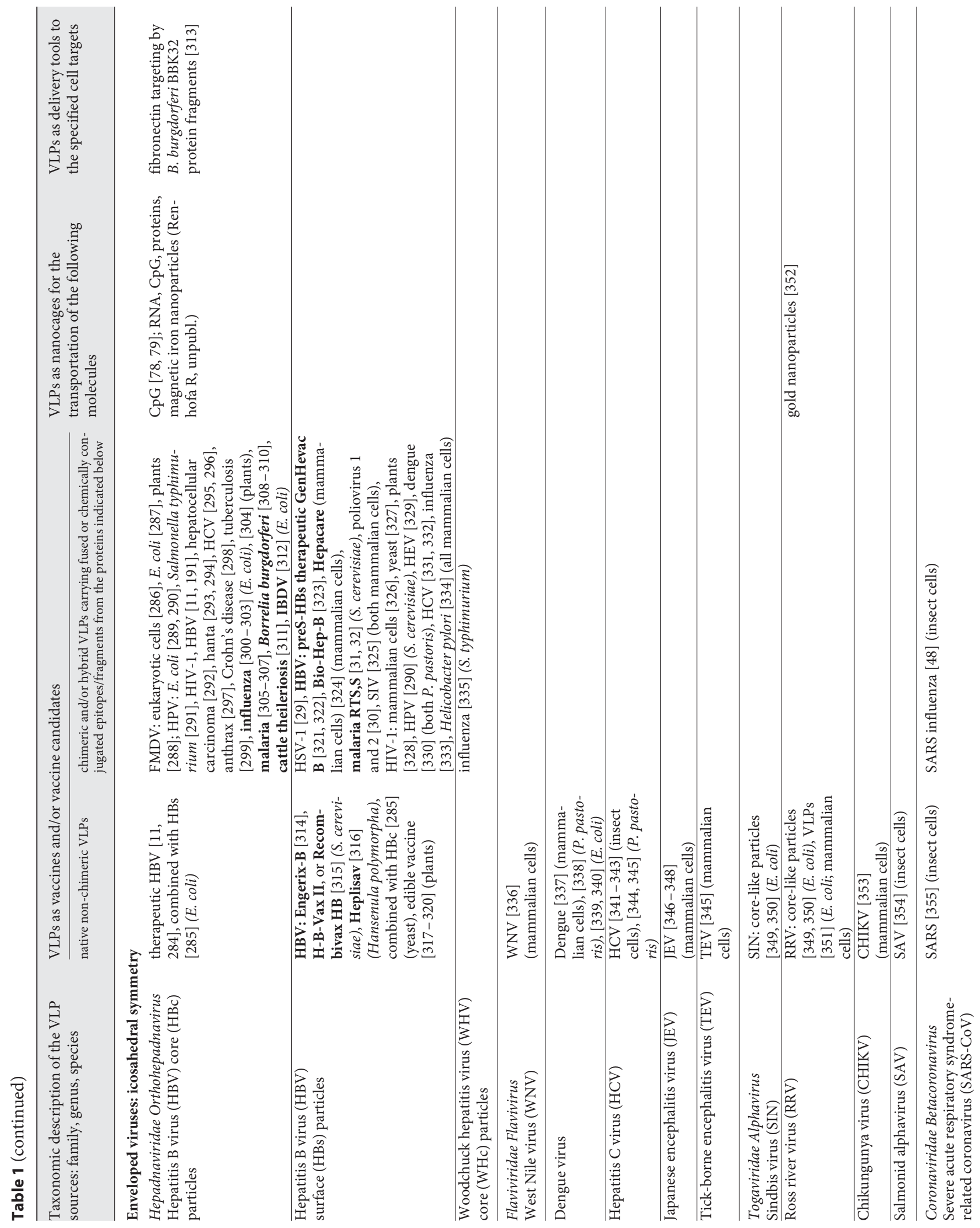




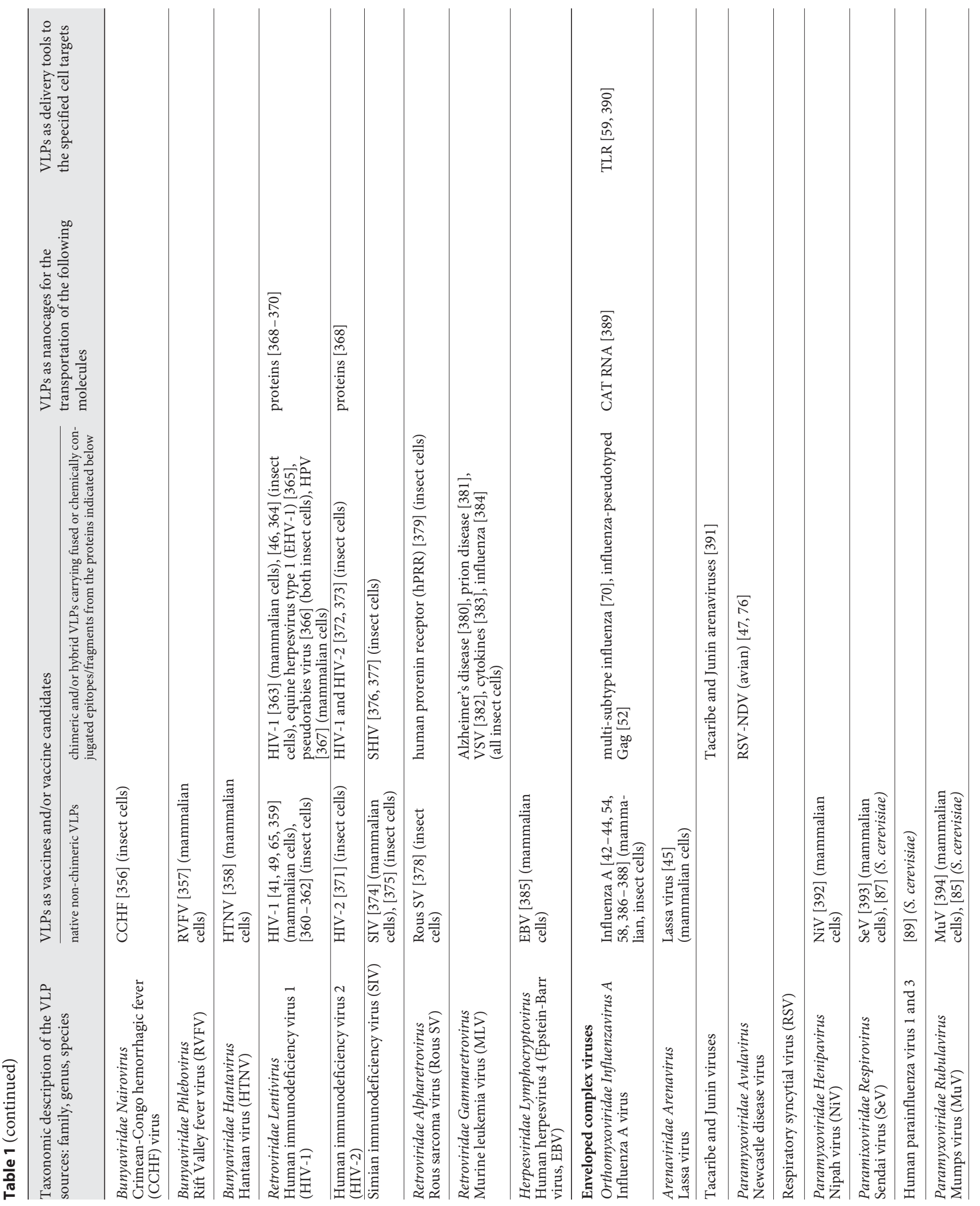


Rod-shaped plant viruses of helical symmetry provide a number of replication-competent examples allowing the production of chimeric viruses, with the exception of potexviruses (papaya and bamboo mosaic viruses and PVX) and some potyviruses (JGMV, PVA, and PVY), which accept foreign insertions in the VLPs after propagation in E. coli and baculovirus expression systems (for references, see table 1 ).

\section{Complex VLPs Derived from Enveloped Viruses}

\section{Construction of Complex Enveloped VLPs}

Enveloped viruses are widely used for the development of VLPs. The viral envelope represents a lipoprotein membrane that surrounds a nucleocapsid $[36,37]$. The lipid bilayer is derived from host cell membranes and contains embedded viral proteins responsible for receptor recognition or other functions. It can also include carbohydrates and proteins derived from the host cell. Envelope proteins usually contain hydrophobic domains that allow their localization within the lipid bilayer. Similar to non-enveloped VLPs, the repeated regular patterns of epitopes in the native conformation make complex enveloped VLPs exceptionally effective immunogens [24, 38].

From the point of view of their spatial structure, the majority of viral envelopes are asymmetrical. However, for some enveloped viruses, viral proteins within the envelope reflect the symmetry of the inner nucleocapsid. For example, alphaviruses contain 240 heterodimers of E2-E1 proteins arranged in an icosahedral lattice according to the 240 subunits of the capsid protein within the inner icosahedral nucleocapsid $[39,40]$. Other viruses, such as the orthomyxovirus influenza virus, contain envelopes that do not possess an apparent regular geometric symmetry, although they may contain elements of symmetry such as the trimers of hemagglutinin (HA) or tetramers of neuraminidase (NA) in influenza viruses.

The preparation of complex enveloped VLPs is challenging. Unlike simple icosahedral particles, enveloped VLPs often contain multiple species of lipid-associated structural proteins. In most cases, the protein-protein interactions and the roles of the proteins, lipids, and host cell factors in the assembly of VLPs are not fully understood. To achieve correct assembly of enveloped VLPs, proper interactions must occur between the nucleocapsid proteins, between the envelope proteins within the lipid bilayer, and between the envelope and the nucleocapsid proteins. The production must include an appropriate cell line and expression system, which should express suf- 
ficient quantities of enveloped VLPs that are immunologically similar to their cognate virus, including the arrangement of the proteins within the envelope. Furthermore, purification of enveloped VLPs can be a difficult task. During production and purification of VLPs, various cellular lipids, carbohydrates, proteins, and nucleic acids co-purify with VLPs, which may cause difficulties in purification as well as safety and regulatory concerns if VLPs are intended for clinical applications.

Despite the challenges, enveloped VLPs of several viruses have been constructed, including VLPs for HIV, influenza viruses, Ebola virus, Lassa virus, and other viruses (table 1). VLPs have been shown to induce advantageous immune responses compared with soluble recombinant proteins. For example, membrane-embedded HIV-1 envelope proteins on the surface of VLPs elicited broader immune responses than did soluble envelope proteins [41]. Similarly, influenza VLPs containing HA protein within the envelope demonstrated greater immunogenicity than subunit HA $[19,42,43]$. In some studies, native enveloped VLPs could be made with unmodified viral proteins [19, 38, 44-46]. In other cases, extensive optimization and engineering of component proteins were required to generate VLPs [46-48].

\section{Rational Design of Enveloped VLPs}

Rational design of VLPs has been used extensively to improve the properties of enveloped VLPs, including expression levels, stability, immunogenicity, and other characteristics. First, attempts have been made to improve the expression of component proteins to improve the production of the assembled VLPs. For example, codon optimization of the expressed viral genes has improved the expression of HIV and HTLV-1 VLPs [49, 50]. Second, efforts have been made to optimize the composition of VLPs and the interactions between the individual VLP components. For example, in many cases, influenza VLPs were prepared using HA, NA, and M1 proteins derived from the same strain [19, 42-44]. Other configurations of VLPs have included a heterologous M1 derived from an unrelated influenza virus strain [51] or even a retrovirus Gag protein in place of M1 [52]. Furthermore, influenza VLPs have been made from HA and NA only [53], from HA and M1 proteins only [54], and from NA and M1 only [55]. VLPs have also been generated in the presence of additional influenza virus proteins, such as M2 [56-58], or in the presence of immunostimulatory antigens such as flagellin, a ligand for Toll-like receptor 5 [59]. These studies have helped elucidate the contributions of individual components to in- fluenza VLP formation. For example, M1 protein is the major component of the virus and an important antigen due to the presence of subtype cross-reactive epitopes [60]. However, the role of M1 in the formation of VLPs or viral particles is not completely understood. According to one view, M1 is the driving force for influenza virus particle formation, penetrating through the cell membrane from inside the cell and interacting with the cytoplasmic tails (CT) of the structural glycoproteins HA and NA during budding [61-63]. An alternative model suggests that HA and NA partition into lipid raft microdomains and recruit the internal viral components, including M1, into the budding viral particle [53]. VLP studies have shown that VLPs can be formed either with or without M1, suggesting both M1-dependent and M1independent mechanisms of VLP formation. This hypothesis is further supported by the fact that both M1deficient and M1-containing types of the mature enveloped virions have been observed by cryo-electron microscopy [64].

Rational design has also been applied to HIV VLPs to improve immunogenicity and efficacy. One approach utilized consensus Env protein sequences [65]. To address the sequence diversity in Env sequences, consensus sequences were made for clade $B$ and clade $C$ envelope proteins. The rationale for using a consensus sequence is that the genetic difference between the vaccine strain and any given viral isolate is decreased, and, therefore, a consensus sequence will provide broader vaccine coverage. The consensus Env sequence elicited broader cell-mediated peripheral and mucosal immune responses than did polyvalent and monovalent Env protein vaccines [65]. In another study, the consensus approach was combined with protein engineering methods to increase the density of Env glycoprotein within the VLP envelopes [46]. Chimeric Env gene constructs have been engineered, in which the coding sequences for the signal peptide (SP), transmembrane (TM), and CT domains of HIV-1 Env were replaced with those of other viral or cellular proteins. Substitution of the SP from the honeybee mellitin protein resulted in 3-fold higher expression of recombinant HIV-1 Env on insect cell surfaces and increased Env incorporation into VLPs. Substitution of the HIV TM$\mathrm{CT}$ with sequences derived from mouse mammary tumour virus (MMTV) envelope glycoprotein, influenza virus HA, or baculovirus (BV) gp64, but not Lassa fever virus glycoprotein, was shown to enhance Env incorporation into VLPs. The highest level of Env incorporation into VLPs was observed in constructs containing the MMTV and BV gp64 TM-CT domains in which the Gag/ 
Env molar ratios were estimated to be $4: 1$ and 5:1, respectively, compared with a 56:1 ratio for full-length consensus gp160 [46].

Additional examples of rational design include engineering of simian human immunodeficiency virus (SHIV) VLPs containing mutant HIV Env with reduced glycosylation, variable loop-deleted mutations, or combinations of both types of mutations [66].

\section{Presentation of Foreign Proteins within Enveloped VLPs}

Unlike VLPs from icosahedral viruses such as HPV, which are composed of a specific number of subunits symmetrically arranged in a geometric structure $[67,68]$, enveloped VLPs allow considerable structural flexibility. The lipid bilayer is relatively fluid, allowing greater flexibility than the rigid geometric lattice of icosahedral VLPs. This flexibility may provide considerable structural capacity and allow the expression of large epitopes or even entire foreign proteins as an integral part of enveloped VLPs.

In addition to accommodating larger foreign epitopes, the structural flexibility of enveloped VLPs makes possible the preparation of chimeric and hybrid VLPs that colocalize proteins from distinct strains or even from distinct viruses.

Influenza VLPs have been used as carriers for foreign antigenic epitopes or proteins. For example, it has been shown that influenza VLPs can incorporate vesicular stomatitis virus (VSV) G protein [56]. As mentioned previously, influenza VLPs can also incorporate flagellin [59]. In another study, Bacillus anthracis protective antigen (BPA) fragments 90 or 140 aa in length were inserted at the C-terminal flank of the HA SP and expressed as the HA1 subunit [69]. The chimeric proteins could be cleaved into the HA1 and HA2 subunits by trypsin and incorporated into influenza viruses, suggesting that the viral envelope can tolerate foreign insertions without precluding assembly. The inserted BPA domains were maintained in the HA gene segments following several passages in MDCK cells or embryonated chicken eggs. Immunization of mice with viruses that expressed the chimeric BPA/HA proteins induced antibody responses against both the HA and BPA components of the protein [69]. Although VLPs were not generated in this study, these experiments suggest that similar modifications of HA with foreign epitopes may be compatible with the formation of chimeric influenza VLPs.

A novel influenza VLP platform containing HA subtypes derived from three distinct strains has also been re-

From Highly Symmetric to Complex VLP Carriers ported [70]. This recombinant VLP design resulted in the expression of three HA subtypes co-localized within a VLP (fig. 2). Experimental triple-HA VLPs containing $\mathrm{HA}$ proteins derived from seasonal H1N1, H3N2, and type B influenza viruses were immunogenic and protected ferrets from challenge with all three seasonal viruses. Similarly, VLPs containing HA subtypes derived from $\mathrm{H} 5 \mathrm{~N} 1, \mathrm{H} 7 \mathrm{~N} 2$, and $\mathrm{H} 2 \mathrm{~N} 2$ viruses protected ferrets from three potentially pandemic influenza viruses [70]. This technology may represent a novel strategy for the rapid development of trivalent seasonal and pandemic influenza vaccines.

The possibility of co-localizing proteins from distinct viruses within the VLP is somewhat similar to the phenotypic mixing that has been observed with live viruses. Phenotypic mixing of proteins from different enveloped viruses has been described between SV5, a paramyxovirus, and VSV, a rhabdovirus, as well as between Sendai and VSV $[71,72]$. Reassortant viruses have also been generated by co-infection of embryonated chicken eggs with influenza type A and type B viruses [73]. Recently, liveattenuated chimeric viruses containing $\mathrm{HA}$ from $\mathrm{A} / \mathrm{PR} 8$ (H1), A/HK68 (H3), or A/VN (H5) strains in the backbone of the $\mathrm{B} /$ Yamagata/88 virus were reported [74]. Reassortment is routinely used in licensed influenza vaccines. In the reassortant vaccine virus, vaccine-relevant $\mathrm{HA}$ and NA glycoproteins are embedded into the envelope, whereas other viral proteins are derived from typespecific donor strains, such as the A/PR/8/34 (H1N1) or B/Ann Arbor/1/66 viruses [75].

In some cases, foreign antigens can only be expressed as VLPs by displaying them within chimeric/hybrid VLPs. For example, VLPs composed entirely of RSV proteins were produced at levels that were inadequate for their use as vaccines [47]. However, VLPs composed of the Newcastle disease virus (NDV) nucleocapsid and membrane proteins and chimeric proteins containing the ectodomains of RSV F and G proteins fused to the TM and cytoplasmic domains of NDV F and HN proteins, respectively, were quantitatively prepared from cultured avian cells. Immunization with a single dose of VLPs resulted in the complete protection of mice against RSV replication in lungs [47]. Another chimeric VLP was composed of the NP and M proteins of NDV and a chimeric protein containing the cytoplasmic and TM domains of the NDV HN protein and the ectodomain of the human RSV G protein (H/G) [76]. The VLP-H/G candidate vaccine was immunogenic in $\mathrm{BALB} / \mathrm{c}$ mice and prevented replication of RSV in murine lungs with no evidence of immunopathology [76]. Chimeric VLPs consist- 
Fig. 2. Preparation and electron microscopy of a triple-subtype VLP vaccine containing seasonal influenza $\mathrm{A} \mathrm{H} 1$ and $\mathrm{H} 3$ subtypes and influenza B virus HA. Recombinant baculovirus (rBV) for the expression of the triple-HA VLPs in Sf9 cells contained influenza HA gene sequences derived from $\mathrm{A} / \mathrm{New}$ Caledonia/20/1999 (H1N1), A/New York/55/2004 (H3N2) and $\mathrm{B} /$ Shanghai/361/2002. NA and M1 gene sequences were from the A/Indonesia/05/2005 (H5N1) virus [70]. Negative stain transmission electron microscopy (bottom middle) was performed by staining with $1 \%$ phosphotungstic acid. Immunoelectron microscopy (bottom right) was performed using sucrose gradient-purified VLPs. VLPs were probed with a mixture of primary antibodies specific for $\mathrm{H} 1, \mathrm{H} 3$, and type B influenza from rabbit, mouse, and guinea pigs, respectively. Secondary antibodies were donkey anti-rabbit labelled with 18-nm gold particles, anti-mouse labelled with 6-nm gold particles, and antiguinea pig labelled with 12-nm gold particles. Bars: $100 \mathrm{~nm}$.

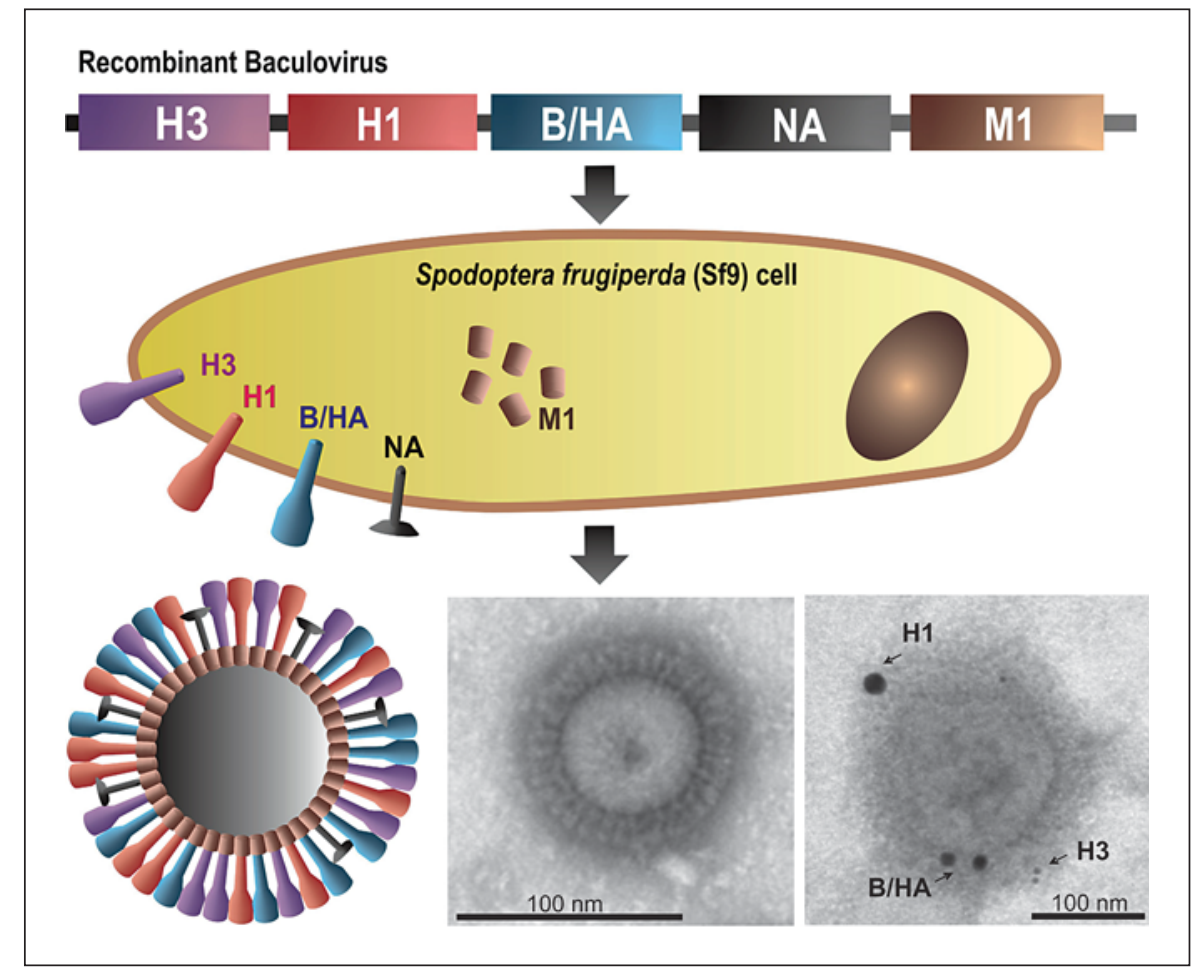

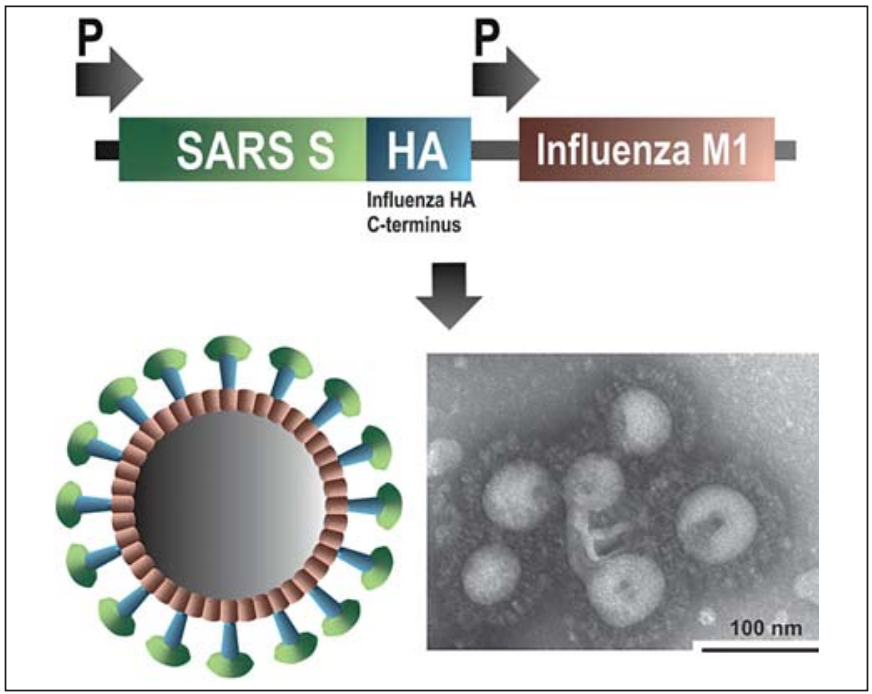

Fig. 3. Preparation of hybrid/chimeric SARS-CoV VLPs using influenza M1 protein and chimeric SARS-CoV S protein (GenBank AAP13441), containing a carboxy-terminal TM sequence derived from influenza HA. TM helices were predicted using TransMem based upon a Hidden Markov Model. The TM domain was derived from influenza A/Indonesia/5/2005 HA (aa 531-568). Chimeric SARS-CoV S and influenza M1 proteins (ABI36004) were co-expressed from recombinant baculovirus in Spodoptera frugiperda Sf9 cells [48]. An electron photomicrograph of hybrid/chimeric SARS-CoV VLPs is shown with a schematic model. ing of an influenza virus matrix (M1) protein core and RSV-F or RSV-G on the surface have also been produced [77]. These data support the further development of VLPs as vaccines for protection against RSV.

Similar to RSV VLPs, VLPs composed entirely of SARS-CoV proteins have been produced at low levels [48]. A method was developed to produce higher levels of SARS VLPs containing the SARS spike (S) protein and the influenza M1 protein (fig. 3). The SARS VLPs protected mice from death when administered via the intramuscular or intranasal routes [48].

\section{Conclusions}

It has been more than 25 years since the idea of using highly symmetric self-assembling VLPs for vaccine purposes attracted considerable attention (fig. 1). Applications of VLPs have included their use as carriers to improve the immunogenicity of poorly immunogenic epitopes. With time, over-optimistic expectations for simple and rapid generation of effective VLP-based vaccines have encountered numerous challenges. Nevertheless, as shown in this review, many promising vaccine candidates have been produced (table 1). Renewal of the 
previous optimism is due at least in part to the recent development of VLPs of large complex viruses, such as orthomyxoviruses, filoviruses, and paramyxoviruses. Due to their larger size and versatile structure, complex VLPs demonstrate greater capacity and flexibility than highly symmetric icosahedral VLPs for the inclusion of full-length, properly folded foreign proteins. Furthermore, complex VLPs are capable of simultaneously accepting various foreign proteins, enabling construction of multivalent vaccines. Full-length foreign proteins or epitopes delivered by large complex VLPs offer many immunological advantages over short epitopes, which have been inserted onto the surface of icosahedral scaffolds. First, complex VLPs can enhance T helper and cytotoxic $\mathrm{T}$ cell responses by inducing highly specific immunological responses directed against conformational epitopes, which is difficult to achieve with chimeric symmetric VLPs. Second, due to their size and organization, complex VLPs may be stable in the blood and thereby obviate the need for adjuvants. Third, if necessary, complex VLPs can be configured to contain specific and efficient adjuvants, including immune stimulatory sequences such as CpGs [78-81]. The presence of a lipid envelope may contribute to the correct folding of certain vaccine antigens and thereby improve immunogenicity. For example, the immunogenicity of purified subunit HA could be improved by adding liposomes [19]. The immunogenicity of split influenza vaccines could also be improved by adding liposomes or lipid-based adjuvants, such as MF59, an oil-in-water emulsion containing the unsaturated aliphatic hydrocarbon squalene [82]. Interestingly, highly immunogenic influenza vaccines, such as whole virus vaccines, VLPs, and virosomes, all have a lipid component in common, suggesting that lipids may play an important role in influenza vaccine immunogenicity.

Growing interest in knowledge-based applications of complex VLPs is strengthened by the development of high-resolution methods $[64,83,84]$.

The rapid development of therapeutic candidates based on complex VLPs is propelled by the constant progress of cGMP-compliant production systems, such as baculovirus system-driven production, and the recent approval of a baculovirus-derived HPV VLP vaccine by the US Food and Drug Administration and other regulatory agencies (table 1). However, purification of complex enveloped VLPs to a standard that meets regulatory and safety requirements can be a difficult task. Unlike icosahedral VLPs such as HPV, complex enveloped VLPs are difficult to purify by conventional methods such as re- folding in vitro. Therefore, the icosahedral VLP platform remains a good option for many applications due to the advantages of purification as well as a clear regulatory pathway due to the availability of licensed vaccines. The introduction of yeast expression systems into the production of complex VLPs can potentially improve the safety and quality control of biotechnological processes [8591].

One potential method for the development of VLPbased vaccines may involve the combination of both complex and icosahedral particles, from a simple mixing of potential vaccine candidates (e.g., the therapeutic hepatitis B vaccine DV-601, http://www.dynavax.com/hepatitis_bt.html) to the knowledge-based packaging of small icosahedral VLPs into large complex VLPs in the future.

Finally, both symmetric and complex VLPs, which were initially used primarily for vaccine development, are now evolving in the direction of broader applications, including gene and drug therapies. New applications for VLPs include the targeting of specific cells and encapsidation of new materials, from oligonucleotides, genes, proteins, and peptides to therapeutic drugs and inorganic compounds such as gold and iron nanoparticles. For each application, careful consideration of both non-enveloped and enveloped VLPs may be necessary.

\section{Acknowledgments}

We are grateful to Vijay S. Reddy (San Diego, Calif., USA) for the three-dimensional images of VLPs, to Kaspars Tars, Andris Dishlers, and Andris Zeltins for critical reading of the manuscript, and to Regina Renhofa and Andris Kazaks (Riga, Latvia) for providing unpublished data. This work was supported by USDA grant 2011-33610-30433 (P. Pushko) and Latvian grants 2010/0261/ 2DP/2.1.1.1.0/10/APIA/VIAA/052 and 2010/0224/2DP/2.1.1.1.0/ 10/APIA/VIAA/164.
References
1 Gren EJ, Pumpen PP: Recombinant viral cap- sids as a new age of immunogenic proteins and vaccines (in Russian). J All-Union Men- deleyev's Chem Soc 1988;33:531-536.
2 Kingsman SM, Kingsman AJ: Polyvalent re- combinant antigens: a new vaccine strategy. Vaccine 1988;6:304-306.
3 Ulrich R, Gerlich WH, Krüger DH: Chimaera and its modern virus-like descendants. Inter- virology 1996;39:126-132.
4 Johnson JE, Chiu W: Structures of virus and virus-like particles. Curr Opin Struct Biol 2000;10:229-235. 
5 Pumpens P, Grens E: Artificial genes for chimeric virus-like particles; in Khudyakov YE, Fields HA (eds): Artificial DNA: Methods and Applications. Boca Raton, CRC Press LLC, 2002, pp 249-327.

6 Bachmann MF, Dyer MR: Therapeutic vaccination for chronic diseases: a new class of drugs in sight. Nat Rev Drug Discov 2004;3: 81-88.

7 Pasek M, Goto T, Gilbert W, Zink B, Schaller H, MacKay P, Leadbetter G, Murray K: Hepatitis $\mathrm{B}$ virus genes and their expression in $E$. coli. Nature 1979;282:575-579.

8 Borisova GP, Pumpen PP, Bychko VV, Pushko PM, Kalis IV, Dishler AV, Gren EJ, Tsibinogin VV, Kukaine RA: Structure and expression in Escherichia coli cells of the core antigen gene of the human hepatitis $B$ virus (HBV) (in Russian). Dokl Akad Nauk SSSR 1984;279:1245-1249.

9 Nassal M: Total chemical synthesis of a gene for hepatitis B virus core protein and its functional characterisation. Gene 1988;66:279294.

10 Valenzuela P, Medina A, Rutter WJ, Ammerer G, Hall BD: Synthesis and assembly of hepatitis B virus surface antigen particles in yeast. Nature 1982;298:347-350.

11 Pumpens P, Ulrich R, Sasnauskas K, Kazaks A, Ose V, Grens E: Construction of novel vaccines on the basis of the virus-like particles: hepatitis $B$ virus proteins as vaccine carriers in Khudyakov Y (ed): Medicinal Protein Engineering. Boca Raton, CRC Press, Taylor \& Francis Group, 2008, pp 205-248.

-12 Kastelein RA, Berkhout B, Overbeek GP, van Duin J: Effect of the sequences upstream from the ribosome-binding site on the yield of protein from the cloned gene for phage MS2 coat protein. Gene 1983;23:245-254.

13 Kozlovskaia TM, Pumpen PP, Drělinia DE, Tsimanis AIu, Ose VP, Tsibinogin VV, Gren EJ: Formation of capsid-like structures as a result of expression of the cloned gene of the envelope protein of the RNA-containing bacteriophage fr (in Russian). Dokl Akad Nauk SSSR 1986;287:452-455.

14 Borisova G, Bundule M, Grinstein E, Dreilina D, Dreimane A, Kalis J, Kozlovskaya T, Loseva V, Ose V, Pumpen P, Pushko P, Snikere D, Stankevica E, Tsibinogin V, Gren EJ: Recombinant capsid structures for exposure of protein antigenic epitopes. Mol Gen (Life Sci Adv) 1987;6:169-174.

15 Kozlovskaia TM, Pushko PM, Stankevich EI, Dreĭmane AIa, Sniker DI, Grinstein EE, Dreilinia DE, Veinia AE, Ose VP, Pumpen PP, Gren EJ: Genetically engineered mutants of the envelope protein of the RNA-containing bacteriophage fr (in Russian). Mol Biol (Mosk) 1988;22:731-740.

16 Kozlovska TM, Cielens I, Dreilinna D, Dislers A, Baumanis V, Ose V, Pumpens P: Recombinant RNA phage $Q$ beta capsid particles synthesized and self-assembled in Escherichia coli. Gene 1993;137:133-137.
17 Haynes JR, Cunnigham J, von Seefried A, Lennick M, Garvin RT, Shen SH: Development of a genetically-engineered, candidate polio vaccine employing the self-assembling properties of the tobacco mosaic virus coat protein. Biotechnology (NY) 1986;4:637-641.

18 Warfield KL, Bosio CM, Welcher BC, Deal EM, Mohamadzadeh M, Schmaljohn A, Aman MJ, Bavari S: Ebola virus-like particles protect from lethal Ebola virus infection. Proc Natl Acad Sci USA 2003;100:15889-15894.

19 Pushko P, Tumpey TM, Van Hoeven N, Belser JA, Robinson R, Nathan M, Smith G, Wright DC, Bright RA: Evaluation of influenza virus-like particles and Novasome adjuvant as candidate vaccine for avian influenza. Vaccine 2007;25:4283-4290.

20 Pushko PM, Bright RA, Tumpey TM, Smith GE: Engineering better influenza vaccines: traditional and new approaches; in Khudyakov Y (ed): Medicinal Protein Engineering. Boca Raton, CRC Press, Taylor \& Francis Group, 2008, pp 169-204.

21 Chackerian B: Virus-like particles: flexible platforms for vaccine development. Expert Rev Vaccines 2007;6:381-390.

22 Ramqvist T, Andreasson K, Dalianis T: Vaccination, immune and gene therapy based on virus-like particles against viral infections and cancer. Expert Opin Biol Ther 2007;7:9971007.

23 Jennings GT, Bachmann MF: Immunodrugs: therapeutic VLP-based vaccines for chronic diseases. Annu Rev Pharmacol Toxicol 2009; 49:303-326.

24 Roy P, Noad R: Virus-like particles as a vaccine delivery system: myths and facts. Adv Exp Med Biol 2009;655:145-158.

25 Whitacre DC, Lee BO, Milich DR: Use of hepadnavirus core proteins as vaccine platforms. Expert Rev Vaccines 2009;8:15651573.

26 Herbst-Kralovetz M, Mason HS, Chen Q Norwalk virus-like particles as vaccines. Expert Rev Vaccines 2010;9:299-307.

27 Roldão A, Mellado MC, Castilho LR, Carrondo MJ, Alves PM: Virus-like particles in vaccine development. Expert Rev Vaccines 2010; 9:1149-1176.

28 Schiller JT, Lowy DR: Vaccines to prevent infections by oncoviruses. Annu Rev Microbiol 2010;64:23-41.

29 Valenzuela P, Coit D, Medina-Selby MA, Kuo CH, Van Nest G, Burke RL, Bull P, Urdea MS, Graves PV: Antigen engineering in yeast: synthesis and assembly of hybrid hepatitis B surface antigen - herpes simplex $1 \mathrm{gD}$ particles. Biotechnology (NY) 1985;3:323-326.

30 Delpeyroux F, Chenciner N, Lim A, Malpièce $\mathrm{Y}$, Blondel B, Crainic R, van der Werf S, Streeck RE: A poliovirus neutralization epitope expressed on hybrid hepatitis B surface antigen particles. Science 1986;233:472-475.
31 Rutgers T, Cordon D, Gathoye AM, Hollingdale M, Hockmeyer W, Rosenberg M, De Wilde M: Hepatitis B surface antigen as carrier matrix for the repetitive epitope of the circumspo rozoite protein of Plasmodium falciparum. Biotechnology (NY) 1988;6:10651070.

- 32 Asante KP, Abdulla S, Agnandji S, Lyimo J, Vekemans J, Soulanoudjingar S, Owusu R, Shomari M, Leach A, Jongert E, Salim N, Fernandes JF, Dosoo D, Chikawe M, Issifou S, Osei-Kwakye K, Lievens M, Paricek M, Möller T, Apanga S, Mwangoka G, Dubois MC, Madi T, Kwara E, Minja R, Hounkpatin AB, Boahen O, Kayan K, Adjei G, Chandramohan D, Carter T, Vansadia P, Sillman M, Savarese B, Loucq C, Lapierre D, Greenwood B, Cohen J, Kremsner P, Owusu-Agyei S, Tanner M, Lell B: Safety and efficacy of the RTS,S/AS01E candidate malaria vaccine given with expanded-programme-on-immunisation vaccines: 19 month follow-up of a randomised, openlabel, phase 2 trial. Lancet Infect Dis 2011;11: 741-749.

33 Steinmetz NF, Lin T, Lomonossoff GP, Johnson JE: Structure-based engineering of an icosahedral virus for nanomedicine and nanotechnology. Curr Top Microbiol Immunol 2009;327:23-58.

-34 Kao CC, Ni P, Hema M, Huang X, Dragnea B: The coat protein leads the way: an update on basic and applied studies with the Brome mosaic virus coat protein. Mol Plant Pathol 2011; 12:403-412.

35 Soto CM, Ratna BR: Virus hybrids as nanomaterials for biotechnology. Curr Opin Biotechnol 2010;21:426-438.

-36 Nayak DP, Balogun RA, Yamada H, Zhou $\mathrm{ZH}$, Barman S: Influenza virus morphogenesis and budding. Virus Res 2009;143:147-161.

37 Vaney MC, Rey FA: Class II enveloped viruses. Cell Microbiol 2011;13:1451-1459.

38 Warfield KL, Posten NA, Swenson DL, Olinger GG, Esposito D, Gillette WK, Hopkins RF, Costantino J, Panchal RG, Hartley JL, Aman MJ, Bavari S: Filovirus-like particles produced in insect cells: immunogenicity and protection in rodents. J Infect Dis 2007; 196(suppl 2):S421-S429.

39 Strauss JH, Strauss EG: The alphaviruses: gene expression, replication, and evolution. Microbiol Rev 1994;58:491-562.

40 Strauss JH, Strauss EG: Virus evolution: how does an enveloped virus make a regular structure? Cell 2001;105:5-8.

41 McBurney SP, Young KR, Ross TM: Membrane embedded HIV-1 envelope on the surface of a virus-like particle elicits broader immune responses than soluble envelopes. $\mathrm{Vi}$ rology 2007;358:334-346.

42 Bright RA, Carter DM, Daniluk S, Toapanta FR, Ahmad A, Gavrilov V, Massare M, Pushko P, Mytle N, Rowe T, Smith G, Ross TM: Influenza virus-like particles elicit broader immune responses than whole virion inactivated influenza virus or recombinant hemagglutinin. Vaccine 2007;25:3871-3878. 
-43 Perrone LA, Ahmad A, Veguilla V, Lu X, 54 Quan FS, Huang C, Compans RW, Kang SM: Smith G, Katz JM, Pushko P, Tumpey TM: Intranasal vaccination with 1918 influenza virus-like particles protects mice and ferrets from lethal 1918 and H5N1 influenza virus challenge. J Virol 2009;83:5726-5734.

44 Pushko P, Tumpey TM, Bu F, Knell J, Robinson R, Smith G: Influenza virus-like particles comprised of the HA, NA, and M1 proteins of H9N2 influenza virus induce protective immune responses in BALB/c mice. Vaccine 2005;23:5751-5759.

45 Branco LM, Grove JN, Geske FJ, Boisen ML, Muncy IJ, Magliato SA, Henderson LA, Schoepp RJ, Cashman KA, Hensley LE, Garry RF: Lassa virus-like particles displaying all major immunological determinants as a vaccine candidate for Lassa hemorrhagic fever. Virol J 2010;7:279.

46 Wang BZ, Liu W, Kang SM, Alam M, Huang C, Ye L, Sun Y, Li Y, Kothe DL, Pushko P, Dokland T, Haynes BF, Smith G, Hahn BH, Compans RW: Incorporation of high levels of chimeric human immunodeficiency virus envelope glycoproteins into virus-like particles. J Virol 2007;81:10869-10878.

47 McGinnes LW, Gravel KA, Finberg RW, Kurt-Jones EA, Massare MJ, Smith G, Schmidt MR, Morrison TG: Assembly and immunological properties of Newcastle disease virus-like particles containing the respiratory syncytial virus $F$ and $G$ proteins. J Virol 2011;85:366-377.

-48 Liu YV, Massare MJ, Barnard DL, Kort T, Nathan M, Wang L, Smith G: Chimeric severe acute respiratory syndrome coronavirus (SARS-CoV) S glycoprotein and influenza matrix 1 efficiently form virus-like particles (VLPs) that protect mice against challenge with SARS-CoV. Vaccine 2011;29:66066613.

49 Diaz-Griffero F, Taube R, Muehlbauer SM, Brojatsch J: Efficient production of HIV-1 viral-like particles in mouse cells. Biochem Biophys Res Commun 2008;368:463-469.

50 Grigsby IF, Zhang W, Johnson JL, Fogarty $\mathrm{KH}$, Chen Y, Rawson JM, Crosby AJ, Mueller JD, Mansky LM: Biophysical analysis of HTLV-1 particles reveals novel insights into particle morphology and Gag stochiometry. Retrovirology 2010;7:75.

-51 Prel A, Le Gall-Reculé G, Jestin V: Achievement of avian influenza virus-like particles that could be used as a subunit vaccine against low-pathogenic avian influenza strains in ducks. Avian Pathol 2008;37:513-520.

52 Haynes JR, Dokken L, Wiley JA, Cawthon AG, Bigger J, Harmsen AG, Richardson C: Influenza-pseudotyped Gag virus-like particle vaccines provide broad protection against highly pathogenic avian influenza challenge. Vaccine 2009;27:530-541.

53 Chen BJ, Leser GP, Morita E, Lamb RA: Influenza virus hemagglutinin and neuraminidase, but not the matrix protein, are required for assembly and budding of plasmid-derived virus-like particles. J Virol 2007;81:7111-7123.
Virus-like particle vaccine induces protective immunity against homologous and heterologous strains of influenza virus. J Virol 2007; 81:3514-3524.

55 Quan FS, Kim MC, Lee BJ, Song JM, Compans RW, Kang SM: Influenza M1 VLPs containing neuraminidase induce heterosubtypic cross-protection. Virology 2012;430:127135.

56 Latham T, Galarza JM: Formation of wildtype and chimeric influenza virus-like particles following simultaneous expression of only four structural proteins. J Virol 2001;75: 6154-6165.

57 Matassov D, Cupo A, Galarza JM: A novel intranasal virus-like particle (VLP) vaccine designed to protect against the pandemic 1918 influenza A virus (H1N1). Viral Immunol 2007;20:441-452.

58 Watanabe T, Watanabe S, Neumann G, Kida $\mathrm{H}$, Kawaoka Y: Immunogenicity and protective efficacy of replication-incompetent influenza virus-like particles. J Virol 2002;76:767773.

59 Wang BZ, Quan FS, Kang SM, Bozja J, Skountzou I, Compans RW: Incorporation of membrane-anchored flagellin into influenza virus-like particles enhances the breadth of immune responses. J Virol 2008;82:1181311823.

60 Terajima M, Cruz J, Leporati AM, Orphin L, Babon JA, Co MD, Pazoles P, Jameson J, Ennis FA: Influenza A virus matrix protein 1-specific human CD8+ T-cell response induced in trivalent inactivated vaccine recipients. J Virol 2008;82:9283-9287.

61 Gómez-Puertas P, Albo C, Pérez-Pastrana E, Vivo A, Portela A: Influenza virus matrix protein is the major driving force in virus budding. J Virol 2000;74:11538-11547.

62 Barman S, Ali A, Hui EK, Adhikary L, Nayak DP: Transport of viral proteins to the apical membranes and interaction of matrix protein with glycoproteins in the assembly of influenza viruses. Virus Res 2001;77:61-69.

63 Schmitt AP, Lamb RA: Influenza virus assembly and budding at the viral budozone. Adv Virus Res 2005;64:383-416.

64 Harris A, Cardone G, Winkler DC, Heymann JB, Brecher M, White JM, Steven AC: Influenza virus pleiomorphy characterized by cryoelectron tomography. Proc Natl Acad Sci USA 2006;103:19123-19127.

65 McBurney SP, Ross TM: Human immunodeficiency virus-like particles with consensus envelopes elicited broader cell-mediated peripheral and mucosal immune responses than polyvalent and monovalent Env vaccines. Vaccine 2009;27:4337-4349.

66 Quan FS, Sailaja G, Skountzou I, Huang C, Vzorov A, Compans RW, Kang SM: Immunogenicity of virus-like particles containing modified human immunodeficiency virus envelope proteins. Vaccine 2007;25:3841-3850.
67 Chen XS, Garcea RL, Goldberg I, Casini G, Harrison SC: Structure of small virus-like particles assembled from the L1 protein of human papillomavirus 16. Mol Cell 2000;5:557567.

68 Sasagawa T, Pushko P, Steers G, Gschmeissner SE, Hajibagheri MA, Finch J, Crawford L, Tommasino M: Synthesis and assembly of virus-like particles of human papillomaviruses type 6 and type 16 in fission yeast Schizosaccharomyces pombe. Virology 1995;206:126135.

69 Li ZN, Mueller SN, Ye L, Bu Z, Yang C, Ahmed R, Steinhauer DA: Chimeric influenza virus hemagglutinin proteins containing large domains of the Bacillus anthracis protective antigen: protein characterization, incorporation into infectious influenza viruses, and antigenicity. J Virol 2005;79:1000310012.

70 Pushko P, Pearce MB, Ahmad A, Tretyakova I, Smith G, Belser JA, Tumpey TM: Influenza virus-like particle can accommodate multiple subtypes of hemagglutinin and protect from multiple influenza types and subtypes. Vaccine 2011;29:5911-5918.

71 Choppin PW, Compans RW: Phenotypic mixing of envelope proteins of the parainfluenza virus SV 5 and vesicular stomatitis virus. J Virol 1970;5:609-616.

72 Metsikkö K, Garoff H: Role of heterologous and homologous glycoproteins in phenotypic mixing between Sendai virus and vesicular stomatitis virus. J Virol 1989;63:5111-5118.

73 Gotlieb T, Hirst GK: The experimental production of combination forms of virus. III. The formation of doubly antigenic particles from influenza A and B virus and a study of the ability of individual particles of $\mathrm{X}$ virus to yield two separate strains. J Exp Med 1954;99: 307-320.

74 Hai R, García-Sastre A, Swayne DE, Palese P: A reassortment-incompetent live attenuated influenza virus vaccine for protection against pandemic virus strains. J Virol 2011;85:68326843.

75 Chen Z, Aspelund A, Kemble G, Jin H: Molecular studies of temperature-sensitive replication of the cold-adapted B/Ann Arbor/1/66, the master donor virus for live attenuated influenza FluMist vaccines. Virology 2008;380: 354-362.

76 Murawski MR, McGinnes LW, Finberg RW, Kurt-Jones EA, Massare MJ, Smith G, Heaton PM, Fraire AE, Morrison TG: Newcastle disease virus-like particles containing respiratory syncytial virus $\mathrm{G}$ protein induced protection in $\mathrm{BALB} / \mathrm{c}$ mice, with no evidence of immunopathology. J Virol 2010;84:11101123.

77 Quan FS, Kim Y, Lee S, Yi H, Kang SM, Bozja J, Moore ML, Compans RW: Viruslike particle vaccine induces protection against respiratory syncytial virus infection in mice. J Infect Dis 2011;204:987-995. 
-78 Storni T, Ruedl C, Schwarz K, Schwendener RA, Renner WA, Bachmann MF: Nonmethylated CG motifs packaged into virus-like particles induce protective cytotoxic $\mathrm{T}$ cell responses in the absence of systemic side effects. J Immunol 2004;172:1777-1785.

-79 Kazaks A, Balmaks R, Voronkova T, Ose V, Pumpens P: Melanoma vaccine candidates from chimeric hepatitis B core virus-like particles carrying a tumor-associated MAGE-3 epitope. Biotechnol J 2008;3:1429-1436.

-80 Senti G, Johansen P, Haug S, Bull C, Gottschaller C, Müller P, Pfister T, Maurer P, Bachmann MF, Graf N, Kündig TM: Use of A-type CpG oligodeoxynucleotides as an adjuvant in allergen-specific immunotherapy in humans: a phase I/IIa clinical trial. Clin Exp Allergy 2009;39:562-570.

81 Krieg AM: CpG still rocks! Update on an accidental drug. Nucleic Acid Ther 2012;22:7789.

82 Podda A: The adjuvanted influenza vaccines with novel adjuvants: experience with the MF59-adjuvanted vaccine. Vaccine 2001;19: 2673-2680.

83 Terrier O, Rolland JP, Rosa-Calatrava M, Lina B, Thomas D, Moules V: Parainfluenza virus type 5 (PIV-5) morphology revealed by cryoelectron microscopy.Virus Res 2009;142: 200-203.

-84 Badia-Martinez D, Peralta B, Andrés G, Guerra M, Gil-Carton D, Abrescia NG: Three-dimensional visualization of forming hepatitis $\mathrm{C}$ virus-like particles by electron-tomography. Virology 2012;430:120-126.

85 Slibinskas R, Zvirbliene A, Gedvilaite A, Samuel D, Jin L, Beard S, Staniulis J, Sasnauskas K: Synthesis of mumps virus nucleocapsid protein in yeast Pichia pastoris. J Biotechnol 2003; 103:43-49.

-86 Slibinskas R, Samuel D, Gedvilaite A, Staniulis J, Sasnauskas K: Synthesis of the measles virus nucleoprotein in yeast Pichia pastoris and Saccharomyces cerevisiae. J Biotechnol 2004;107:115-124.

87 Juozapaitis M, Slibinskas R, Staniulis J, Sakaguchi T, Sasnauskas K: Generation of Sendai virus nucleocapsid-like particles in yeast. Virus Res 2005;108:221-224.

88 Juozapaitis M, Serva A, Kucinskaite I, Zvirbliene A, Slibinskas R, Staniulis J, Sasnauskas K, Shiell BJ, Bowden TR, Michalski WP: Generation of menangle virus nucleocapsid-like particles in yeast Saccharomyces cerevisiae. J Biotechnol 2007;130:441-447.

89 Juozapaitis M, Zvirbliene A, Kucinskaite I, Sezaite I, Slibinskas R, Coiras M, de Ory Manchon F, López-Huertas MR, Pérez-Breña P, Staniulis J, Narkeviciute I, Sasnauskas K: Synthesis of recombinant human parainfluenza virus 1 and 3 nucleocapsid proteins in yeast Saccharomyces cerevisiae. Virus Res 2008;133: 178-186.
90 Petraityte R, Tamosiunas PL, Juozapaitis M, Zvirbliene A, Sasnauskas K, Shiell B, Russell G, Bingham J, Michalski WP: Generation of Tioman virus nucleocapsid-like particles in yeast Saccharomyces cerevisiae. Virus Res 2009;145:92-96.

-91 Petraitytė-Burneikienè R, Nalivaiko K, Lasickienė R, Firantienė R, Emužytė R, Sasnauskas K, Zvirblienè A: Generation of recombinant metapneumovirus nucleocapsid protein as nucleocapsid-like particles and development of virus-specific monoclonal antibodies. Virus Res 2011;161:131-139.

\$2 Bucarey SA, Noriega J, Reyes P, Tapia C, Sáenz L, Zuñiga A, Tobar JA: The optimized capsid gene of porcine circovirus type 2 expressed in yeast forms virus-like particles and elicits antibody responses in mice fed with recombinant yeast extracts. Vaccine 2009;27:5781-5790.

\$3 Wu PC, Lin WL, Wu CM, Chi JN, Chien MS, Huang C: Characterization of porcine circovirus type 2 (PCV2) capsid particle assembly and its application to virus-like particle vaccine development. Appl Microbiol Biotechnol 2012;95:1501-1507.

-94 Bansal GP, Hatfield JA, Dunn FE, Kramer AA, Brady F, Riggin CH, Collett MS, Yoshimoto K, Kajigaya S, Young NS: Candidate recombinant vaccine for human B19 parvovirus. J Infect Dis 1993;167:1034-1044.

95 Bernstein DI, El Sahly HM, Keitel WA, Wolff M, Simone G, Segawa C, Wong S, Shelly D, Young NS, Dempsey W: Safety and immunogenicity of a candidate parvovirus B19 vaccine. Vaccine 2011;29:7357-7363.

\$96 Brown CS, Welling-Wester S, Feijlbrief M, Van Lent JW, Spaan WJ: Chimeric parvovirus B19 capsids for the presentation of foreign epitopes. Virology 1994;198:477-488.

-97 Amexis G, Young NS: Parvovirus B19 empty capsids as antigen carriers for presentation of antigenic determinants of dengue 2 virus. J Infect Dis 2006;194:790-794.

98 Ogasawara Y, Amexis G, Yamaguchi H, Kajigaya S, Leppla SH, Young NS: Recombinant viral-like particles of parvovirus B19 as antigen carriers of anthrax protective antigen. In Vivo 2006;20:319-324.

99 Hou L, Wu H, Xu L, Yang F: Expression and self-assembly of virus-like particles of infectious hypodermal and hematopoietic necrosis virus in Escherichia coli. Arch Virol 2009; 154:547-553.

$100 \mathrm{Ju}$ H, Wei N, Wang Q, Wang C, Jing Z, Guo L, Liu D, Gao M, Ma B, Wang J: Goose parvovirus structural proteins expressed by recombinant baculoviruses self-assemble into virus-like particles with strong immunogenicity in goose. Biochem Biophys Res Commun 2011;409:131-136.
01 Antonis AF, Bruschke CJ, Rueda P, Maranga L, Casal JI, Vela C, Hilgers LA, Belt PB, Weerdmeester K, Carrondo MJ, Langeveld JP: A novel recombinant virus-like particle vaccine for prevention of porcine parvovirus-induced reproductive failure. Vaccine 2006;24:5481-5490.

102 Sedlik C, Sarraseca J, Rueda P, Leclerc C, Casal I: Immunogenicity of poliovirus B and $\mathrm{T}$ cell epitopes presented by hybrid porcine parvovirus particles. J Gen Virol 1995;76: 2361-2368.

103 Pan Q, He K, Huang K: Development of recombinant porcine parvovirus-like particles as an antigen carrier formed by the hybrid VP2 protein carrying immunoreactive epitope of porcine circovirus type 2. Vaccine 2008;26:2119-2126.

104 López de Turiso JA, Cortés E, Martínez C, Ruiz de Ybáñez R, Simarro I, Vela C, Casal I: Recombinant vaccine for canine parvovirus in dogs. J Virol 1992;66:2748-2753.

105 Rueda P, Martínez-Torrecuadrada JL, Sarraseca J, Sedlik C, del Barrio M, Hurtado A, Leclerc C, Casal JI: Engineering parvoviruslike particles for the induction of B-cell, CD4(+) and CTL responses. Vaccine 1999; 18:325-332.

106 Feng $\mathrm{H}$, Liang M, Wang HL, Zhang T, Zhao PS, Shen XJ, Zhang RZ, Hu GQ, Gao YQ, Wang CY, Wang TC, Zhang W, Yang ST, Xia XZ: Recombinant canine parvoviruslike particles express foreign epitopes in silkworm pupae. Vet Microbiol 2011;154:4957.

107 Singh P: Tumor targeting using canine parvovirus nanoparticles. Curr Top Microbiol Immunol 2009;327:123-141.

108 Maloney BJ, Takeda N, Suzaki Y, Ami Y, Li TC, Miyamura T, Arntzen CJ, Mason HS: Challenges in creating a vaccine to prevent hepatitis E. Vaccine 2005;23:1870-1874.

109 Niikura M, Takamura S, Kim G, Kawai S, Saijo M, Morikawa S, Kurane I, Li TC, Takeda N, Yasutomi Y: Chimeric recombinant hepatitis E virus-like particles as an oral vaccine vehicle presenting foreign epitopes. Virology 2002;293:273-280.

-110 Yusibov V, Hooper DC, Spitsin SV, Fleysh N, Kean RB, Mikheeva T, Deka D, Karasev A, Cox S, Randall J, Koprowski H: Expression in plants and immunogenicity of plant virus-based experimental rabies vaccine. Vaccine 2002;20:3155-3164.

111 Yusibov V, Mett V, Mett V, Davidson C, Musiychuk K, Gilliam S, Farese A, Macvittie T, Mann D: Peptide-based candidate vaccine against respiratory syncytial virus. Vaccine 2005;23:2261-2265.

112 Brodzik R, Bandurska K, Deka D, Golovkin M, Koprowski H: Advances in alfalfa mosaic virus-mediated expression of anthrax antigen in planta. Biochem Biophys Res Commun 2005;338:717-722. 
$\checkmark 113$ Chen C, Daniel MC, Quinkert ZT, De M, Stein B, Bowman VD, Chipman PR, Rotello VM, Kao CC, Dragnea B: Nanoparticle-templated assembly of viral protein cages. Nano Lett 2006;6:611-615.

114 Hu Y, Zandi R, Anavitarte A, Knobler CM, Gelbart WM: Packaging of a polymer by a viral capsid: the interplay between polymer length and capsid size. Biophys J 2008;94: 1428-1436.

-115 Minten IJ, Wilke KD, Hendriks LJ, van Hest JC, Nolte RJ, Cornelissen JJ: Metal-ion-induced formation and stabilization of protein cages based on the cowpea chlorotic mottle virus. Small 2011;7:911-919.

-116 Cadena-Nava RD, Comas-Garcia M, Garmann RF, Rao AL, Knobler CM, Gelbart WM: Self-assembly of viral capsid protein and RNA molecules of different sizes: requirement for a specific high protein/RNA mass ratio. J Virol 2012;86:3318-3326.

-117 Brasch M, de la Escosura A, Ma Y, Uetrecht C, Heck AJ, Torres T, Cornelissen JJ: Encapsulation of phthalocyanine supramolecular stacks into virus-like particles. J Am Chem Soc 2011;133:6878-6881.

118 Nuzzaci M, Vitti A, Condelli V, Lanorte MT, Tortorella C, Boscia D, Piazzolla P, Piazzolla G: In vitro stability of Cucumber mosaic virus nanoparticles carrying a hepatitis $\mathrm{C}$ virus-derived epitope under simulated gastrointestinal conditions and in vivo efficacy of an edible vaccine. J Virol Methods 2010;165: 211-215.

119 Natilla A, Hammond RW, Nemchinov LG: Epitope presentation system based on cucumber mosaic virus coat protein expressed from a potato virus X-based vector. Arch Virol 2006;151:1373-1386.

120 Vitti A, Piazzolla G, Condelli V, Nuzzaci M, Lanorte MT, Boscia D, De Stradis A, Antonaci S, Piazzolla P, Tortorella C: Cucumber mosaic virus as the expression system for a potential vaccine against Alzheimer's disease. J Virol Methods 2010;169:332-340.

-121 Lu X, Thompson JR, Perry KL: Encapsidation of DNA, a protein and a fluorophore into virus-like particles by the capsid protein of cucumber mosaic virus. J Gen Virol 2012; 93:1120-1126.

122 Mastico RA, Talbot SJ, Stockley PG: Multiple presentation of foreign peptides on the surface of an RNA-free spherical bacteriophage capsid. J Gen Virol 1993;74:541-548.

-123 Peabody DS, Manifold-Wheeler B, Medford A, Jordan SK, do Carmo Caldeira J, Chackerian B: Immunogenic display of diverse peptides on virus-like particles of RNA phage MS2. J Mol Biol 2008;380:252-263.

124 Heal KG, Hill HR, Stockley PG, Hollingdale MR, Taylor-Robinson AW: Expression and immunogenicity of a liver stage malaria epitope presented as a foreign peptide on the surface of RNA-free MS2 bacteriophage capsids. Vaccine 1999;18:251-258.
125 Brown WL, Mastico RA, Wu M, Heal KG, Adams CJ, Murray JB, Simpson JC, Lord JM, Taylor-Robinson AW, Stockley PG: RNA bacteriophage capsid-mediated drug delivery and epitope presentation. Intervirology 2002;45:371-380.

126 Wu M, Sherwin T, Brown WL, Stockley PG: Delivery of antisense oligonucleotides to leukemia cells by RNA bacteriophage capsids. Nanomedicine 2005;1:67-76.

127 Wei B, Wei Y, Zhang K, Wang J, Xu R, Zhan S, Lin G, Wang W, Liu M, Wang L, Zhang R, Li J: Development of an antisense RNA delivery system using conjugates of the MS2 bacteriophage capsids and HIV-1 TAT cellpenetrating peptide. Biomed Pharmacother 2009;63:313-318.

128 Sun S, Li W, Sun Y, Pan Y, Li J: A new RNA vaccine platform based on MS2 virus-like particles produced in Saccharomyces cerevisiae. Biochem Biophys Res Commun 2011; 407:124-128.

129 Ashley CE, Carnes EC, Phillips GK, Durfee PN, Buley MD, Lino CA, Padilla DP, Phillips B, Carter MB, Willman CL, Brinker CJ, Caldeira Jdo C, Chackerian B, Wharton W, Peabody DS: Cell-specific delivery of diverse cargos by bacteriophage MS2 virus-like particles. ACS Nano 2011;5:5729-5745.

130 Pan Y, Zhang Y, Jia T, Zhang K, Li J, Wang L: Development of a microRNA delivery system based on bacteriophage MS2 virus-like particles. FEBS J 2012;279:1198-1208.

131 Wu M, Brown WL, Stockley PG: Cell-specific delivery of bacteriophage-encapsidated ricin A chain. Bioconjug Chem 1995;6:587595.

132 Caldeira Jdo C, Medford A, Kines RC, Lino CA, Schiller JT, Chackerian B, Peabody DS: Immunogenic display of diverse peptides, including a broadly cross-type neutralizing human papillomavirus L2 epitope, on viruslike particles of the RNA bacteriophage PP7. Vaccine 2010;28:4384-4393.

133 Tumban E, Peabody J, Peabody DS, Chackerian B: A pan-HPV vaccine based on bacteriophage PP7 VLPs displaying broadly cross-neutralizing epitopes from the HPV minor capsid protein, L2. PLoS One 2011; 6:e23310.

134 Voronkova T, Grosch A, Kazaks A, Ose V, Skrastina D, Sasnauskas K, Jandrig B, Arnold W, Scherneck S, Pumpens P, Ulrich R: Chimeric bacteriophage fr virus-like particles harboring the immunodominant C-terminal region of hamster polyomavirus VP1 induce a strong VP1-specific antibody response in rabbits and mice. Viral Immunol 2002;15:627-643.

135 Rūmnieks J, Freivalds J, Cielēns I, Renhofa R: Packaging of specific mRNAs in bacteriophage GA virus-like particles in yeast Saccharomyces cerevisiae. Acta Universitatis Latviensis Biol 2008;745:145-154.
36 Tissot AC, Renhofa R, Schmitz N, Cielens I, Meijerink E, Ose V, Jennings GT, Saudan P, Pumpens P, Bachmann MF: Versatile viruslike particle carrier for epitope based vaccines. PLoS One 2010;5:e9809.

137 Spohn G, Jennings GT, Martina BE, Keller I, Beck M, Pumpens P, Osterhaus AD, Bachmann MF: A VLP-based vaccine targeting domain III of the West Nile virus E protein protects from lethal infection in mice. Virol J 2010;7:146.

138 Klimek L, Willers J, Hammann-Haenni A, Pfaar O, Stocker H, Mueller P, Renner WA, Bachmann MF: Assessment of clinical efficacy of CYT003-QbG10 in patients with allergic rhinoconjunctivitis: a phase IIb study Clin Exp Allergy 2011;41:1305-1312.

139 Vasiljeva I, Kozlovska T, Cielens I, Strelnikova A, Kazaks A, Ose V, Pumpens P: Mosaic Qbeta coats as a new presentation model. FEBS Lett 1998;431:7-11.

140 Bessa J, Schmitz N, Hinton HJ, Schwarz K, Jegerlehner A, Bachmann MF: Efficient induction of mucosal and systemic immune responses by virus-like particles administered intranasally: implications for vaccine design. Eur J Immunol 2008;38:114-126.

141 Cornuz J, Zwahlen S, Jungi WF, Osterwalder J, Klingler K, van Melle G, Bangala Y, Guessous I, Müller P, Willers J, Maurer P, Bachmann MF, Cerny T: A vaccine against nicotine for smoking cessation: a randomized controlled trial. PLoS One 2008;3:e2547.

142 Tissot AC, Maurer P, Nussberger J, Sabat R, Pfister T, Ignatenko S, Volk HD, Stocker H, Müller P, Jennings GT, Wagner F, Bachmann MF: Effect of immunisation against angiotensin II with CYT006-AngQb on ambulatory blood pressure: a double-blind, randomised, placebo-controlled phase IIa study. Lancet 2008;371:821-827.

143 Braun M, Jandus C, Maurer P, HammannHaenni A, Schwarz K, Bachmann MF, Speiser DE, Romero P: Virus-like particles induce robust human T-helper cell responses. Eur J Immunol 2012;42:330-340.

144 Spohn G, Keller I, Beck M, Grest P, Jennings GT, Bachmann MF: Active immunization with IL-1 displayed on virus-like particles protects from autoimmune arthritis. Eur J Immunol 2008;38:877-887.

145 Röhn TA, Ralvenius WT, Paul J, Borter P, Hernandez M, Witschi R, Grest P, Zeilhofer HU, Bachmann MF, Jennings GT: A viruslike particle-based anti-nerve growth factor vaccine reduces inflammatory hyperalgesia: potential long-term therapy for chronic pain. J Immunol 2011;186:1769-1780.

146 Wiessner C, Wiederhold KH, Tissot AC, Frey P, Danner S, Jacobson LH, Jennings GT, Lüönd R, Ortmann R, Reichwald J, Zurini M, Mir A, Bachmann MF, Staufenbiel $M$ : The second-generation active $A \beta$ immunotherapy CAD106 reduces amyloid accumulation in APP transgenic mice while minimizing potential side effects. J Neurosci 2011;31:9323-9331. 
147 Fulurija A, Lutz TA, Sladko K, Osto M, Wielinga PY, Bachmann MF, Saudan P: Vaccination against GIP for the treatment of obesity. PLoS One 2008;3:e3163.

-148 Spohn G, Schwarz K, Maurer P, Illges H, Rajasekaran N, Choi Y, Jennings GT, Bachmann MF: Protection against osteoporosis by active immunization with TRANCE/ RANKL displayed on virus-like particles. J Immunol 2005; 175:6211-6218.

-149 Zou Y, Sonderegger I, Lipowsky G, Jennings GT, Schmitz N, Landi M, Kopf M, Bachmann MF: Combined vaccination against IL-5 and eotaxin blocks eosinophilia in mice. Vaccine 2010;28:3192-3200.

150 Hunter Z, Smyth HD, Durfee P, Chackerian $\mathrm{B}$ : Induction of mucosal and systemic antibody responses against the HIV coreceptor CCR5 upon intramuscular immunization and aerosol delivery of a virus-like particle based vaccine. Vaccine 2009;28:403-414.

-151 Schmitz N, Dietmeier K, Bauer M, Maudrich M, Utzinger S, Muntwiler S, Saudan P, Bachmann MF: Displaying Fel d1 on virus-like particles prevents reactogenicity despite greatly enhanced immunogenicity: a novel therapy for cat allergy. J Exp Med 2009;206: 1941-1955.

152 Fiedler JD, Brown SD, Lau JL, Finn MG: RNA-directed packaging of enzymes within virus-like particles. Angew Chem Int Ed Engl 2010;49:9648-9651.

153 Rhee JK, Hovlid M, Fiedler JD, Brown SD, Manzenrieder F, Kitagishi H, Nycholat C, Paulson JC, Finn MG: Colorful virus-like particles: fluorescent protein packaging by the $\mathrm{Q} \beta$ capsid. Biomacromolecules 2011;12: 3977-3981.

-154 Lau JL, Baksh MM, Fiedler JD, Brown SD, Kussrow A, Bornhop DJ, Ordoukhanian P, Finn MG: Evolution and protein packaging of small-molecule RNA aptamers. ACS Nano 2011;5:7722-7729.

155 Wu Z, Tang LJ, Zhang XB, Jiang JH, Tan W: Aptamer-modified nanodrug delivery systems. ACS Nano 2011;5:7696-7699.

-156 Brown SD, Fiedler JD, Finn MG: Assembly of hybrid bacteriophage Qbeta virus-like particles. Biochemistry 2009;48:1115511157.

157 Pokorski JK, Hovlid ML, Finn MG: Cell targeting with hybrid $\mathrm{Q} \beta$ virus-like particles displaying epidermal growth factor. ChemBioChem 2011;12:2441-2447.

158 Gale AJ, Elias DJ, Averell PM, Teirstein PS, Buck M, Brown SD, Polonskaya Z, Udit AK, Finn MG: Engineered virus-like nanoparticles reverse heparin anticoagulation more consistently than protamine in plasma from heparin-treated patients. Thromb Res 2011; 128:e9-e13.

159 Plevka P, Kazaks A, Voronkova T, Kotelovica S, Dishlers A, Liljas L, Tars K: The structure of bacteriophage phiCb5 reveals a role of the RNA genome and metal ions in particle stability and assembly. J Mol Biol 2009; 391:635-647.
60 Brennan FR, Gilleland LB, Staczek J, Bendig MM, Hamilton WD, Gilleland HE Jr: A chimaeric plant virus vaccine protects mice against a bacterial infection. Microbiology 1999;145:2061-2067.

161 Dalsgaard K, Uttenthal A, Jones TD, Xu F, Merryweather A, Hamilton WD, Langeveld JP, Boshuizen RS, Kamstrup S, Lomonossoff GP, Porta C, Vela C, Casal JI, Meloen RH, Rodgers PB: Plant-derived vaccine protects target animals against a viral disease. Nat Biotechnol 1997; 15:248-252.

162 Langeveld JP, Brennan FR, Martínez-Torrecuadrada JL, Jones TD, Boshuizen RS, Vela C, Casal JI, Kamstrup S, Dalsgaard K, Meloen RH, Bendig MM, Hamilton WD: Inactivated recombinant plant virus protects dogs from a lethal challenge with canine parvovirus. Vaccine 2001;19:3661-3670.

163 Aljabali AA, Shah SN, Evans-Gowing R, Lomonossoff GP, Evans DJ: Chemically-coupled-peptide-promoted virus nanoparticle templated mineralization. Integr Biol (Camb) 2011;3:119-125.

164 Blum AS, Soto CM, Sapsford KE, Wilson CD, Moore MH, Ratna BR: Molecular electronics based nanosensors on a viral scaffold. Biosens Bioelectron 2011;26:28522857.

165 Aljabali AA, Lomonossoff GP, Evans DJ: CPMV-polyelectrolyte-templated gold nanoparticles. Biomacromolecules 2011;12: 2723-2728.

166 Sainsbury F, Saunders K, Aljabali AA, Evans DJ, Lomonossoff GP: Peptide-controlled access to the interior surface of empty virus nanoparticles. ChemBioChem 2011;12: 2435-2440.

167 Destito G, Yeh R, Rae CS, Finn MG, Manchester M: Folic acid-mediated targeting of cowpea mosaic virus particles to tumor cells. Chem Biol 2007;14:1152-1162.

168 Steinmetz NF, Cho CF, Ablack A, Lewis JD, Manchester M: Cowpea mosaic virus nanoparticles target surface vimentin on cancer cells. Nanomedicine (Lond) 2011;6: 351-364.

169 Lewis JD, Destito G, Zijlstra A, Gonzalez MJ, Quigley JP, Manchester M, Stuhlmann H: Viral nanoparticles as tools for intravital vascular imaging. Nat Med 2006;12:354-360.

170 Leong HS, Steinmetz NF, Ablack A, Destito G, Zijlstra A, Stuhlmann H, Manchester M, Lewis JD: Intravital imaging of embryonic and tumor neovasculature using viral nanoparticles. Nat Protoc 2010;5:1406-1417.

171 Jeoung HY, Lee WH, Jeong W, Shin BH, Choi HW, Lee HS, An DJ: Immunogenicity and safety of virus-like particle of the porcine encephalomyocarditis virus in pig. Virol J 2011;8:170.

172 Chung YC, Ho MS, Wu JC, Chen WJ, Huang $\mathrm{JH}$, Chou ST, Hu YC: Immunization with virus-like particles of enterovirus 71 elicits potent immune responses and protects mice against lethal challenge. Vaccine 2008;26: 1855-1862.
73 Zhang L, Parham NJ, Zhang F, Aasa-Chapman M, Gould EA, Zhang H: Vaccination with coxsackievirus $B 3$ virus-like particles elicits humoral immune response and protects mice against myocarditis. Vaccine 2012;30:2301-2308.

174 Lee CD, Yan YP, Liang SM, Wang TF: Production of FMDV virus-like particles by a SUMO fusion protein approach in Escherichia coli. J Biomed Sci 2009;16:69.

175 Cao Y, Sun P, Fu Y, Bai X, Tian F, Liu X, Lu Z, Liu Z: Formation of virus-like particles from O-type foot-and-mouth disease virus in insect cells using codon-optimized synthetic genes. Biotechnol Lett 2010;32:12231229.

176 Manayani DJ, Thomas D, Dryden KA, Reddy V, Siladi ME, Marlett JM, Rainey GJ Pique ME, Scobie HM, Yeager M, Young JA, Manchester M, Schneemann A: A viral nanoparticle with dual function as an anthrax antitoxin and vaccine. PLoS Pathog 2007;3:1422-1431.

-177 Kumar S, Ochoa W, Singh P, Hsu C, Schneemann A, Manchester M, Olson M, Reddy V: Tomato bushy stunt virus (TBSV), a versatile platform for polyvalent display of antigenic epitopes and vaccine design. Virology 2009;388:185-190.

178 Thiéry R, Cozien J, Cabon J, Lamour F, Baud $\mathrm{M}$, Schneemann A: Induction of a protective immune response against viral nervous necrosis in the European sea bass Dicentrarchus labrax by using betanodavirus viruslike particles. J Virol 2006;80:10201-10207.

179 Lu MW, Liu W, Lin CS: Infection competition against grouper nervous necrosis virus by virus-like particles produced in Escherichia coli. J Gen Virol 2003;84:1577-1582.

180 Ball JM, Graham DY, Opekun AR, Gilger MA, Guerrero RA, Estes MK: Recombinant Norwalk virus-like particles given orally to volunteers: phase I study. Gastroenterology 1999;117:40-48.

181 Zhang X, Buehner NA, Hutson AM, Estes MK, Mason HS: Tomato is a highly effective vehicle for expression and oral immunization with Norwalk virus capsid protein. Plant Biotechnol J 2006;4:419-432.

-182 Santi L, Batchelor L, Huang Z, Hjelm B, Kilbourne J, Arntzen CJ, Chen Q, Mason HS: An efficient plant viral expression system generating orally immunogenic Norwalk virus-like particles. Vaccine 2008;26:18461854.

183 Atmar RL, Bernstein DI, Harro CD, Al-Ibrahim MS, Chen WH, Ferreira J, Estes MK, Graham DY, Opekun AR, Richardson C, Mendelman PM: Norovirus vaccine against experimental human Norwalk Virus illness. N Engl J Med 2011;365:2178-2187.

184 Laurent S, Vautherot JF, Madelaine MF, Le Gall G, Rasschaert D: Recombinant rabbit hemorrhagic disease virus capsid protein expressed in baculovirus self-assembles into viruslike particles and induces protection. J Virol 1994;68:6794-6798. 
185 Boga JA, Martín Alonso JM, Casais R, Parra F: A single dose immunization with rabbit haemorrhagic disease virus major capsid protein produced in Saccharomyces cerevisiae induces protection. J Gen Virol 1997;78: 2315-2318.

-186 Farnós O, Fernández E, Chiong M, Parra F, Joglar M, Méndez L, Rodríguez E, Moya G, Rodríguez D, Lleonart R, González EM, Alonso A, Alfonso P, Suárez M, Rodríguez MP, Toledo JR: Biochemical and structural characterization of RHDV capsid protein variants produced in Pichia pastoris: advantages for immunization strategies and vaccine implementation. Antiviral Res 2009;81: 25-36.

187 Crisci E, Fraile L, Moreno N, Blanco E, Cabezón R, Costa C, Mussá T, Baratelli M, Martinez-Orellana P, Ganges L, Martínez J, Bárcena J, Montoya M: Chimeric calicivirus-like particles elicit specific immune responses in pigs. Vaccine 2012;30:24272439.

188 Luque D, González JM, Gómez-Blanco J, Marabini R, Chichón J, Mena I, Angulo I, Carrascosa JL, Verdaguer N, Trus BL, Bárcena J, Castón JR: Epitope insertion at the $\mathrm{N}$-terminal molecular switch of the rabbit hemorrhagic disease virus $t=3$ capsid protein leads to larger $\mathrm{t}=4$ capsids. $\mathrm{J}$ Virol 2012; 86:6470-6480.

189 Peacey M, Wilson S, Perret R, Ronchese F, Ward VK, Young V, Young SL, Baird MA: Virus-like particles from rabbit hemorrhagic disease virus can induce an anti-tumor response. Vaccine 2008;26:5334-5337.

190 Win SJ, McMillan DG, Errington-Mais F, Ward VK, Young SL, Baird MA, Melcher AA: Enhancing the immunogenicity of tumour lysate-loaded dendritic cell vaccines by conjugation to virus-like particles. $\mathrm{Br} \mathrm{J}$ Cancer 2012;106:92-98.

-191 Skrastina D, Bulavaite A, Sominskaya I, Kovalevska L, Ose V, Priede D, Pumpens P, Sasnauskas K: High immunogenicity of a hydrophilic component of the hepatitis B virus preS1 sequence exposed on the surface of three virus-like particle carriers. Vaccine 2008;26:1972-1981.

-192 Tegerstedt K, Lindencrona JA, Curcio C, Andreasson K, Tullus C, Forni G, Dalianis T, Kiessling R, Ramqvist T: A single vaccination with polyomavirus VP1/VP2Her2 virus-like particles prevents outgrowth of HER-2/neu-expressing tumors. Cancer Res 2005;65:5953-5957.

193 Andreasson K, Tegerstedt K, Eriksson M, Curcio C, Cavallo F, Forni G, Dalianis T, Ramqvist T: Murine pneumotropic virus chimeric Her2/neu virus-like particles as prophylactic and therapeutic vaccines against Her2/neu expressing tumors. Int J Cancer 2009;124:150-156.
94 Eriksson M, Andreasson K, Weidmann J, Lundberg K, Tegerstedt K, Dalianis $\mathrm{T}$, Ramqvist T: Murine polyomavirus viruslike particles carrying full-length human PSA protect $\mathrm{BALB} / \mathrm{c}$ mice from outgrowth of a PSA expressing tumor. PLoS One 2011; 6:e23828.

195 Middelberg AP, Rivera-Hernandez T, Wibowo N, Lua LH, Fan Y, Magor G, Chang C, Chuan YP, Good MF, Batzloff MR: A microbial platform for rapid and low-cost viruslike particle and capsomere vaccines. Vaccine 2011;29:7154-7162.

196 May T, Gleiter S, Lilie H: Assessment of cell type specific gene transfer of polyoma virus like particles presenting a tumor specific antibody Fv fragment. J Virol Methods 2002; 105:147-157.

197 Gedvilaite A, Frömmel C, Sasnauskas K, Micheel B, Ozel M, Behrsing O, Staniulis J, Jandrig B, Scherneck S, Ulrich R: Formation of immunogenic virus-like particles by inserting epitopes into surface-exposed regions of hamster polyomavirus major capsid protein. Virology 2000;273:21-35.

198 Gedvilaite A, Zvirbliene A, Staniulis J, Sasnauskas K, Krüger DH, Ulrich R: Segments of puumala hantavirus nucleocapsid protein inserted into chimeric polyomavirus-derived virus-like particles induce a strong immune response in mice. Viral Immunol 2004;17:51-68.

199 Dorn DC, Lawatscheck R, Zvirbliene A, Aleksaite E, Pecher G, Sasnauskas K, Ozel M, Raftery M, Schönrich G, Ulrich RG, Gedvilaite A: Cellular and humoral immunogenicity of hamster polyomavirus-derived virus-like particles harboring a mucin 1 cytotoxic T-cell epitope. Viral Immunol 2008;21: $12-27$.

200 Mazeike E, Gedvilaite A, Blohm U: Induction of insert-specific immune response in mice by hamster polyomavirus VP1 derived virus-like particles carrying LCMV GP33 CTL epitope. Virus Res 2012;163:2-10.

201 Pleckaityte M, Zvirbliene A, Sezaite I, Gedvilaite A: Production in yeast of pseudotype virus-like particles harboring functionally active antibody fragments neutralizing the cytolytic activity of vaginolysin. Microb Cell Fact 2011;10:109.

202 Voronkova T, Kazaks A, Ose V, Ozel M, Scherneck S, Pumpens P, Ulrich R: Hamster polyomavirus-derived virus-like particles are able to transfer in vitro encapsidated plasmid DNA to mammalian cells. Virus Genes 2007;34:303-314.

203 Inoue T, Kawano MA, Takahashi RU, Tsukamoto H, Enomoto T, Imai T, Kataoka K, Handa H: Engineering of SV40-based nanocapsules for delivery of heterologous proteins as fusions with the minor capsid proteins VP2/3. J Biotechnol 2008;134:181-192.
204 Li F, Zhang ZP, Peng J, Cui ZQ, Pang DW, Li K, Wei HP, Zhou YF, Wen JK, Zhang XE: Imaging viral behavior in mammalian cells with self-assembled capsid-quantum-dot hybrid particles. Small 2009;5:718-726.

205 Takahashi RU, Kanesashi SN, Inoue T, Enomoto T, Kawano MA, Tsukamoto H, Takeshita F, Imai T, Ochiya T, Kataoka K, Yamaguchi Y, Handa H: Presentation of functional foreign peptides on the surface of SV40 virus-like particles. J Biotechnol 2008; 135:385-392.

206 Kitai Y, Fukuda H, Enomoto T, Asakawa Y, Suzuki T, Inouye $\mathrm{S}$, Handa $\mathrm{H}$ : Cell selective targeting of a simian virus 40 virus-like particle conjugated to epidermal growth factor. J Biotechnol 2011;155:251-256.

207 Chou MI, Hsieh YF, Wang M, Chang JT, Chang D, Zouali M, Tsay GJ: In vitro and in vivo targeted delivery of IL-10 interfering RNA by JC virus-like particles. J Biomed Sci 2010;17:51.

208 Chang CF, Wang M, Ou WC, Chen PL, Shen $\mathrm{CH}$, Lin PY, Fang CY, Chang D: Human JC virus-like particles as a gene delivery vector. Expert Opin Biol Ther 2011;11:1169-1175.

209 Centers for Disease Control and Prevention (CDC): FDA licensure of quadrivalent human papillomavirus vaccine (HPV4, Gardasil) for use in males and guidance from the Advisory Committee on Immunization Practices (ACIP). MMWR Morb Mortal Wkly Rep 2010;59:630-632.

210 Centers for Disease Control and Prevention (CDC): FDA licensure of bivalent human papillomavirus vaccine (HPV2, Cervarix) for use in females and updated HPV vaccination recommendations from the Advisory Committee on Immunization Practices (ACIP). MMWR Morb Mortal Wkly Rep 2010;59:626-629.

211 Dale CJ, Liu XS, De Rose R, Purcell DF, Anderson J, Xu Y, Leggatt GR, Frazer IH, Kent SJ: Chimeric human papilloma virus-simian/human immunodeficiency virus viruslike-particle vaccines: immunogenicity and protective efficacy in macaques. Virology 2002;301:176-187.

212 Greenstone HL, Nieland JD, de Visser KE, De Bruijn ML, Kirnbauer R, Roden RB, Lowy DR, Kast WM, Schiller JT: Chimeric papillomavirus virus-like particles elicit antitumor immunity against the E7 oncoprotein in an HPV16 tumor model. Proc Natl Acad Sci USA 1998;95:1800-1805.

213 Kaufmann AM, Nieland JD, Jochmus I, Baur S, Friese K, Gabelsberger J, Gieseking F, Gissmann L, Glasschröder B, Grubert T, Hillemanns P, Höpfl R, Ikenberg H, Schwarz J, Karrasch M, Knoll A, Küppers V, Lechmann M, Lelle RJ, Meissner H, Müller RT, Pawlita M, Petry KU, Pilch H, Walek E, Schneider A: Vaccination trial with HPV16 L1E7 chimeric virus-like particles in women suffering from high grade cervical intraepithelial neoplasia (CIN 2/3). Int J Cancer 2007;121:2794-2800. 
214 Matić S, Rinaldi R, Masenga V, Noris E: Ef- 224 Zhao KN, Hengst K, Liu WJ, Liu YH, Liu XS, ficient production of chimeric human papillomavirus $16 \mathrm{~L} 1$ protein bearing the M2e influenza epitope in Nicotiana benthamiana plants. BMC Biotechnol 2011;11:106.

-215 Paz De la Rosa G, Monroy-García A, MoraGarcía Mde L, Peña CG, Hernández-Montes J, Weiss-Steider B, Gómez-Lim MA: An HPV 16 L1-based chimeric human papilloma virus-like particles containing a string of epitopes produced in plants is able to elicit humoral and cytotoxic T-cell activity in mice. Virol J 2009;6:2.

-216 Windram OP, Weber B, Jaffer MA, Rybicki EP, Shepherd DN, Varsani A: An investigation into the use of human papillomavirus type 16 virus-like particles as a delivery vector system for foreign proteins: $\mathrm{N}$ - and Cterminal fusion of GFP to the L1 and L2 capsid proteins. Arch Virol 2008;153:585-589.

217 Renoux VM, Fleury MJ, Bousarghin L, Gaitan J, Sizaret PY, Touzé A, Coursaget P: Induction of antibody response against hepatitis E virus (HEV) with recombinant human papillomavirus pseudoviruses expressing truncated HEV capsid proteins in mice. Vaccine 2008;26:6602-6607.

218 Malboeuf CM, Simon DA, Lee YE, Lankes HA, Dewhurst S, Frelinger JG, Rose RC: Human papillomavirus-like particles mediate functional delivery of plasmid DNA to antigen presenting cells in vivo. Vaccine 2007; 25:3270-3276.

-219 Wang H, Yang Z, Li F, He Y, Wang S, Yang $\mathrm{D}, \mathrm{Wu} \mathrm{Y}$ : Insertion of a targeting peptide on capsid surface loops of human papillomavirus type-16 virus-like particles mediate elimination of anti-dsDNA Abs-producing $B$ cells with high efficiency. J Immunother 2009;32:36-41.

-220 Hainisch EK, Brandt S, Shafti-Keramat S, Van den Hoven R, Kirnbauer R: Safety and immunogenicity of BPV-1 L1 virus-like particles in a dose-escalation vaccination trial in horses. Equine Vet J 2012;44:107-111.

-221 Slupetzky K, Gambhira R, Culp TD, ShaftiKeramat S, Schellenbacher C, Christensen ND, Roden RB, Kirnbauer R: A papillomavirus-like particle (VLP) vaccine displaying HPV16 L2 epitopes induces cross-neutralizing antibodies to HPV11. Vaccine 2007;25: 2001-2010.

-222 Zamora E, Handisurya A, Shafti-Keramat S, Borchelt D, Rudow G, Conant K, Cox C, Troncoso JC, Kirnbauer R: Papillomaviruslike particles are an effective platform for amyloid-beta immunization in rabbits and transgenic mice. J Immunol 2006;177:26622670.

-223 Pejawar-Gaddy S, Rajawat Y, Hilioti Z, Xue J, Gaddy DF, Finn OJ, Viscidi RP, Bossis I: Generation of a tumor vaccine candidate based on conjugation of a MUC1 peptide to polyionic papillomavirus virus-like particles. Cancer Immunol Immunother 2010; 59:1685-1696. McMillan NA, Frazer IH: BPV1 E2 protein enhances packaging of full-length plasmid DNA in BPV1 pseudovirions. Virology 2000;272:382-393.

225 Jansen KU, Rosolowsky M, Schultz LD, Markus HZ, Cook JC, Donnelly JJ, Martinez D, Ellis RW, Shaw AR: Vaccination with yeast-expressed cottontail rabbit papillomavirus (CRPV) virus-like particles protects rabbits from CRPV-induced papilloma formation. Vaccine 1995;13:1509-1514.

-226 Breitburd F, Kirnbauer R, Hubbert NL, Nonnenmacher B, Trin-Dinh-Desmarquet C, Orth G, Schiller JT, Lowy DR: Immunization with virus-like particles from cottontail rabbit papillomavirus (CRPV) can protect against experimental CRPV infection. J Virol 1995;69:3959-3963.

227 Govan VA, Rybicki EP, Williamson AL: Therapeutic immunisation of rabbits with cottontail rabbit papillomavirus (CRPV) virus-like particles (VLP) induces regression of established papillomas. Virol J 2008;5:45.

228 Kohl T, Hitzeroth II, Stewart D, Varsani A, Govan VA, Christensen ND, Williamson AL, Rybicki EP: Plant-produced cottontail rabbit papillomavirus L1 protein protects against tumor challenge: a proof-of-concept study. Clin Vaccine Immunol 2006;13:845853.

229 Roy P, Urakawa T, Van Dijk AA, Erasmus $\mathrm{BJ}$ : Recombinant virus vaccine for bluetongue disease in sheep. J Virol 1990;64: 1998-2003.

-230 Stewart M, Bhatia Y, Athmaran TN, Noad R, Gastaldi C, Dubois E, Russo P, Thiéry R, Sailleau C, Bréard E, Zientara S, Roy P: Validation of a novel approach for the rapid production of immunogenic virus-like particles for bluetongue virus. Vaccine 2010;28: 3047-3054.

-231 Pérez de Diego AC, Athmaram TN, Stewart M, Rodríguez-Sánchez B, Sánchez-Vizcaíno JM, Noad R, Roy P: Characterization of protection afforded by a bivalent virus-like particle vaccine against bluetongue virus serotypes 1 and 4 in sheep. PLoS One 2011; 6:e26666.

232 Stewart M, Dovas CI, Chatzinasiou E, Athmaram TN, Papanastassopoulou M, Papadopoulos O, Roy P: Protective efficacy of Bluetongue virus-like and subvirus-like particles in sheep: presence of the serotype-specific VP2, independent of its geographic lineage, is essential for protection. Vaccine 2012;30:2131-2139.

233 Belyaev AS, Roy P: Presentation of hepatitis B virus preS2 epitope on bluetongue virus core-like particles. Virology 1992;190:840844.

234 Le Blois H, Roy P: A single point mutation in the VP7 major core protein of bluetongue virus prevents the formation of core-like particles. J Virol 1993;67:353-359.
235 Adler S, Reay P, Roy P, Klenk HD: Induction of $\mathrm{T}$ cell response by bluetongue virus corelike particles expressing a $\mathrm{T}$ cell epitope of the M1 protein of influenza A virus. Med Microbiol Immunol 1998;187:91-96.

236 Guthrie AJ, Quan M, Lourens CW, Audonnet JC, Minke JM, Yao J, He L, Nordgren R, Gardner IA, Maclachlan NJ: Protective immunization of horses with a recombinant canarypox virus vectored vaccine co-expressing genes encoding the outer capsid proteins of African horse sickness virus. Vaccine 2009;27:4434-4438.

237 Rutkowska DA, Meyer QC, Maree F, Vosloo W, Fick W, Huismans H: The use of soluble African horse sickness viral protein 7 as an antigen delivery and presentation system. Virus Res 2011;156:35-48.

238 Crawford SE, Estes MK, Ciarlet M, Barone C, O'Neal CM, Cohen J, Conner ME: Heterotypic protection and induction of a broad heterotypic neutralization response by rotavirus-like particles. J Virol 1999;73:48134822.

239 González AM, Nguyen TV, Azevedo MS, Jeong K, Agarib F, Iosef C, Chang K, Lovgren-Bengtsson K, Morein B, Saif LJ: Antibody responses to human rotavirus (HRV) in gnotobiotic pigs following a new prime/boost vaccine strategy using oral attenuated HRV priming and intranasal VP2/6 rotavirus-like particle (VLP) boosting with ISCOM. Clin Exp Immunol 2004; 135:361-372.

240 Azevedo MS, Gonzalez AM, Yuan L, Jeong KI, Iosef C, Van Nguyen T, Lovgren-Bengtsson K, Morein B, Saif LJ: An oral versus intranasal prime/boost regimen using attenuated human rotavirus or VP2 and VP6 viruslike particles with immunostimulating complexes influences protection and antibody-secreting cell responses to rotavirus in a neonatal gnotobiotic pig model. Clin Vaccine Immunol 2010;17:420-428.

241 Blazevic V, Lappalainen S, Nurminen K, Huhti L, Vesikari T: Norovirus VLPs and rotavirus VP6 protein as combined vaccine for childhood gastroenteritis. Vaccine 2011;29: 8126-8133.

242 Istrate C, Hinkula J, Charpilienne A, Poncet D, Cohen J, Svensson L, Johansen K: Parenteral administration of $\mathrm{RF} 8-2 / 6 / 7$ rotavirus-like particles in a one-dose regimen induce protective immunity in mice. Vaccine 2008;26:4594-4601.

243 Cortes-Perez NG, Sapin C, Jaffrelo L, Daou S, Grill JP, Langella P, Seksik P, Beaugerie L, Chwetzoff S, Trugnan G: Rotavirus-like particles: a novel nanocarrier for the gut. J Biomed Biotechnol 2010;2010:317545.

244 Gilbert SC, Plebanski M, Harris SJ, Allsopp CE, Thomas R, Layton GT, Hill AV: A protein particle vaccine containing multiple malaria epitopes. Nat Biotechnol 1997;15: $1280-1284$. 
245 Plebanski M, Gilbert SC, Schneider J, Han- 255 Garcel A, Gout E, Timmins J, Chroboczek J, nan CM, Layton G, Blanchard T, Becker M, Smith G, Butcher G, Sinden RE, Hill AV: Protection from Plasmodium berghei infection by priming and boosting $\mathrm{T}$ cells to a single class I-restricted epitope with recombinant carriers suitable for human use. Eur J Immunol 1998;28:4345-4355.

246 Oliveira-Ferreira J, Miyahira Y, Layton GT, Savage N, Esteban M, Rodriguez D, Rodriguez JR, Nussenzweig RS, Zavala F: Immunogenicity of Ty-VLP bearing a CD8(+) T cell epitope of the CS protein of $P$. yoelii: enhanced memory response by boosting with recombinant vaccinia virus. Vaccine 2000; 18:1863-1869.

-247 Adams SE, Dawson KM, Gull K, Kingsman SM, Kingsman AJ: The expression of hybrid HIV:Ty virus-like particles in yeast. Nature 1987;329:68-70.

-248 Martin SJ, Vyakarnam A, Cheingsong-Popov R, Callow D, Jones KL, Senior JM, Adams SE, Kingsman AJ, Matear P, Gotch FM, et al: Immunization of human HIV-seronegative volunteers with recombinant p17/p24:Ty virus-like particles elicits HIV-1 p24-specific cellular and humoral immune responses. AIDS 1993; 7:1315-1323.

-249 Peters BS, Cheingsong-Popov R, Callow D, Foxall R, Patou G, Hodgkin K, Weber JN: A pilot phase II study of the safety and immunogenicity of HIV p17/p24:VLP (p24-VLP) in asymptomatic HIV seropositive subjects. J Infect 1997;35:231-235.

-250 Layton GT, Harris SJ, Myhan J, West D, Gotch F, Hill-Perkins M, Cole JS, Meyers N, Woodrow S, French TJ, Adams SE, Kingsman AJ: Induction of single and dual cytotoxic T-lymphocyte responses to viral proteins in mice using recombinant hybrid $\mathrm{Ty}$ virus-like particles. Immunology 1996;87: 171-178.

-251 Tang KH, Yusoff K, Tan WS: Display of hepatitis B virus PreS1 peptide on bacteriophage T7 and its potential in gene delivery into HepG2 cells. J Virol Methods 2009;159:194199.

252 Uchida M, Morris DS, Kang S, Jolley CC, Lucon J, Liepold LO, LaFrance B, Prevelige PE Jr, Douglas T: Site-directed coordination chemistry with P22 virus-like particles. Langmuir 2012;28:1998-2006.

-253 Mattiacio J, Walter S, Brewer M, Domm W, Friedman AE, Dewhurst S: Dense display of HIV-1 envelope spikes on the lambda phage scaffold does not result in the generation of improved antibody responses to HIV-1 Env. Vaccine 2011;29:2637-2647.

254 Villegas-Mendez A, Garin MI, Pineda-Molina E, Veratti E, Bueren JA, Fender P, Lenormand JL: In vivo delivery of antigens by adenovirus dodecahedron induces cellular and humoral immune responses to elicit antitumor immunity. Mol Ther 2010;18:10461053.
Fender P: Protein transduction into human cells by adenovirus dodecahedron using WW domains asuniversal adaptors. J Gene Med 2006;8:524-531.

256 Zochowska M, Paca A, Schoehn G, Andrieu JP, Chroboczek J, Dublet B, Szolajska E: Adenovirus dodecahedron, as a drug delivery vector. PLoS One 2009;4:e5569.

257 Denis J, Acosta-Ramirez E, Zhao Y, Hamelin ME, Koukavica I, Baz M, Abed Y, Savard C, Pare C, Lopez Macias C, Boivin G, Leclerc D: Development of a universal influenza A vaccine based on the M2e peptide fused to the papaya mosaic virus (PapMV) vaccine platform. Vaccine 2008;26: 3395-3403.

258 Savard C, Laliberté-Gagné MẼ, Babin C, Bolduc M, Guérin A, Drouin K, Forget MA, Majeau N, Lapointe R, Leclerc D: Improvement of the PapMV nanoparticle adjuvant property through an increased of its avidity for the antigen [influenza NP]. Vaccine 2012;30:2535-2542.

259 Marusic C, Rizza P, Lattanzi L, Mancini C, Spada M, Belardelli F, Benvenuto E, Capone I: Chimeric plant virus particles as immunogens for inducing murine and human immune responses against human immunodeficiency virus type 1. J Virol 2001;75:84348439.

260 Uhde K, Fischer R, Commandeur U: Expression of multiple foreign epitopes presented as synthetic antigens on the surface of Potato virus X particles. Arch Virol 2005;150: 327-340.

261 Zelada AM, Calamante G, de la Paz Santangelo M, Bigi F, Verna F, Mentaberry A, Cataldi A: Expression of tuberculosis antigen ESAT-6 in Nicotiana tabacum using a potato virus X-based vector. Tuberculosis (Edinb) 2006;86:263-267.

262 Lico C, Mancini C, Italiani P, Betti C, Boraschi D, Benvenuto E, Baschieri S: Plant-produced potato virus $\mathrm{X}$ chimeric particles displaying an influenza virus-derived peptide activate specific CD8+ T cells in mice. Vaccine 2009;27:5069-5076.

263 Uhde-Holzem K, Schlösser V, Viazov S, Fischer R, Commandeur U: Immunogenic properties of chimeric potato virus $\mathrm{X}$ particles displaying the hepatitis $\mathrm{C}$ virus hypervariable region I peptide R9. J Virol Methods 2010;166:12-20.

264 Plchova H, Moravec T, Hoffmeisterova H, Folwarczna J, Cerovska N: Expression of Human papillomavirus 16 E7ggg oncoprotein on $\mathrm{N}$ - and C-terminus of Potato virus $\mathrm{X}$ coat protein in bacterial and plant cells. Protein Expr Purif 2011;77:146-152.

265 Cerovska N, Hoffmeisterova H, Moravec T, Plchova H, Folwarczna J, Synkova H, Ryslava H, Ludvikova V, Smahel M: Transient expression of human papillomavirus type 16 L2 epitope fused to $\mathrm{N}$ - and C-terminus of coat protein of Potato virus $\mathrm{X}$ in plants. J Biosci 2012;37:125-133.
66 Steinmetz NF, Mertens ME, Taurog RE, Johnson JE, Commandeur U, Fischer R, Manchester M: Potato virus X as a novel platform for potential biomedical applications. Nano Lett 2010;10:305-312.

267 Yang CD, Liao JT, Lai CY, Jong MH, Liang CM, Lin YL, Lin NS, Hsu YH, Liang SM: Induction of protective immunity in swine by recombinant bamboo mosaic virus expressing foot-and-mouth disease virus epitopes. BMC Biotechnol 2007;7:62.

268 Chen TH, Chen TH, Hu CC, Liao JT, Lee CW, Liao JW, Lin MY, Liu HJ, Wang MY, Lin NS, Hsu YH: Induction of protective immunity in chickens immunized with plantmade chimeric Bamboo mosaic virus particles expressing very virulent infectious bursal disease virus antigen. Virus Res 2012;166: 109-115.

269 Jagadish MN, Hamilton RC, Fernandez CS, Schoofs P, Davern KM, Kalnins H, Ward CW, Nisbet IT: High level production of hybrid potyvirus-like particles carrying repetitive copies of foreign antigens in Escherichia coli. Biotechnology (NY) 1993;11:1166-1170.

270 Saini M, Vrati S: A Japanese encephalitis virus peptide present on Johnson grass mosaic virus-like particles induces virus-neutralizing antibodies and protects mice against lethal challenge. J Virol 2003;77:3487-3494.

-271 Choudhury S, Kakkar V, Suman P, Chakrabarti K, Vrati S, Gupta SK: Immunogenicity of zona pellucida glycoprotein-3 and spermatozoa YLP(12) peptides presented on Johnson grass mosaic virus-like particles. Vaccine 2009;27:2948-2953.

-272 Jacquet C, Ravelonandro M, Dunez J: High resistance and control of biological risks in transgenic plants expressing modified plum poxvirus coat protein. Acta Virol 1998;42: 235-237.

273 Fernández-Fernández MR, Martínez-Torrecuadrada JL, Casal JI, García JA: Development of an antigen presentation system based on plum pox potyvirus. FEBS Lett 1998;427:229-235.

274 Kalnciema I, Skrastina D, Ose V, Pumpens $\mathrm{P}$, Zeltins A: Potato virus Y-like particles as a new carrier for the presentation of foreign protein stretches. Mol Biotechnol 2012;52: 129-139.

275 Fujiyama K, Saejung W, Yanagihara I, Nakado J, Misaki R, Honda T, Watanabe Y, Seki $\mathrm{T}$ : In Planta production of immunogenic poliovirus peptide using tobacco mosaic virusbased vector system. J Biosci Bioeng 2006; 101:398-402.

276 Turpen TH, Reinl SJ, Charoenvit Y, Hoffman SL, Fallarme V, Grill LK: Malarial epitopes expressed on the surface of recombinant tobacco mosaic virus. Biotechnology (NY) 1995;13:53-57.

277 Sugiyama Y, Hamamoto H, Takemoto S, Watanabe Y, Okada Y: Systemic production of foreign peptides on the particle surface of tobacco mosaic virus. FEBS Lett 1995;359: 247-250. 
278 Bendahmane M, Koo M, Karrer E, Beachy RN: Display of epitopes on the surface of tobacco mosaic virus: impact of charge and isoelectric point of the epitope on virus-host interactions. J Mol Biol 1999;290:9-20.

$\checkmark 279$ Koo M, Bendahmane M, Lettieri GA, Paoletti AD, Lane TE, Fitchen JH, Buchmeier MJ, Beachy RN: Protective immunity against murine hepatitis virus (MHV) induced by intranasal or subcutaneous administration of hybrids of tobacco mosaic virus that carries an MHV epitope. Proc Natl Acad Sci USA 1999;96:7774-7779.

280 Staczek J, Bendahmane M, Gilleland LB, Beachy RN, Gilleland HE Jr: Immunization with a chimeric tobacco mosaic virus containing an epitope of outer membrane protein F of Pseudomonas aeruginosa provides protection against challenge with $P$. aeruginosa. Vaccine 2000;18:2266-2274.

-281 Wu L, Jiang L, Zhou Z, Fan J, Zhang Q, Zhu H, Han Q, Xu Z: Expression of foot-andmouth disease virus epitopes in tobacco by a tobacco mosaic virus-based vector. Vaccine 2003;21:4390-4398

-282 Palmer KE, Benko A, Doucette SA, Cameron TI, Foster T, Hanley KM, McCormick AA, McCulloch M, Pogue GP, Smith ML, Christensen ND: Protection of rabbits against cutaneous papillomavirus infection using recombinant tobacco mosaic virus containing L2 capsid epitopes. Vaccine 2006;24:5516-5525.

-283 Mueller A, Kadri A, Jeske H, Wege C: In vitro assembly of Tobacco mosaic virus coat protein variants derived from fission yeast expression clones or plants. J Virol Methods 2010;166:77-85.

-284 Kutscher S, Bauer T, Dembek C, Sprinzl M, Protzer U: Design of therapeutic vaccines: hepatitis B as an example. Microb Biotechnol 2012;5:270-282.

-285 Betancourt AA, Delgado CA, Estévez ZC, Martínez JC, Ríos GV, Aureoles-Roselló SR, Zaldívar RA, Guzmán MA, Baile NF, Reyes PA, Ruano LO, Fernández AC, Lobaina-Matos Y, Fernández AD, Madrazo AI, Martínez MI, Baños ML, Alvarez NP, Baldo MD, Mestre RE, Pérez MV, Martínez ME, Escobar DA, Guanche MJ, Cáceres LM, Betancourt RS, Rando EH, Nieto GE, González VL, Rubido JC: Phase I clinical trial in healthy adults of a nasal vaccine candidate containing recombinant hepatitis B surface and core antigens. Int J Infect Dis 2007;11:394-401.

-286 Clarke BE, Newton SE, Carroll AR, Francis MJ, Appleyard G, Syred AD, Highfield PE, Rowlands DJ, Brown F: Improved immunogenicity of a peptide epitope after fusion to hepatitis B core protein. Nature 1987;330: 381-384.

287 Zhang YL, Guo YJ, Wang KY, Lu K, Li K, Zhu Y, Sun SH: Enhanced immunogenicity of modified hepatitis B virus core particle fused with multiepitopes of foot-and-mouth disease virus. Scand J Immunol 2007;65: 320-328.
288 Huang Y, Liang W, Wang Y, Zhou Z, Pan A, Yang X, Huang C, Chen J, Zhang D: Immunogenicity of the epitope of the foot-andmouth disease virus fused with a hepatitis $B$ core protein as expressed in transgenic tobacco. Viral Immunol 2005; 18:668-677.

289 Tindle RW, Herd K, Londoño P, Fernando GJ, Chatfield SN, Malcolm K, Dougan G: Chimeric hepatitis B core antigen particles containing B- and Th-epitopes of human papillomavirus type $16 \mathrm{E} 7$ protein induce specific antibody and T-helper responses in immunised mice. Virology 1994;200:547557.

290 Pumpens P, Razanskas R, Pushko P, Renhof R, Gusars I, Skrastina D, Ose V, Borisova G, Sominskaya I, Petrovskis I, Jansons J, Sasnauskas $\mathrm{K}$ : Evaluation of $\mathrm{HBs}, \mathrm{HBc}$, and frCP virus-like particles for expression of human papillomavirus 16 E7 oncoprotein epitopes. Intervirology 2002;45:24-32.

291 Londoño LP, Chatfield S, Tindle RW, Herd K, Gao XM, Frazer I, Dougan G: Immunisation of mice using Salmonella typhimurium expressing human papillomavirus type 16 E7 epitopes inserted into hepatitis B virus core antigen. Vaccine 1996;14:545-552.

292 Ding FX, Wang F, Lu YM, Li K, Wang KH, He XW, Sun SH: Multiepitope peptide-loaded virus-like particles as a vaccine against hepatitis B virus-related hepatocellular carcinoma. Hepatology 2009;49:1492-1502. 293 Ulrich R, Lundkvist A, Meisel H, Koletzki D,
Sjölander KB, Gelderblom HR, Borisova G, Schnitzler P, Darai G, Krüger DH: Chimaeric $\mathrm{HBV}$ core particles carrying a defined segment of Puumala hantavirus nucleocapsid protein evoke protective immunity in an animal model. Vaccine 1998;16:272-280.

294 Geldmacher A, Skrastina D, Borisova G, Petrovskis I, Krüger DH, Pumpens P, Ulrich R: A hantavirus nucleocapsid protein segment exposed on hepatitis B virus core particles is highly immunogenic in mice when applied without adjuvants or in the presence of pre-existing anti-core antibodies. Vaccine 2005;23:3973-3983

295 Mihailova M, Boos M, Petrovskis I, Ose V, Skrastina D, Fiedler M, Sominskaya I, Ross S, Pumpens P, Roggendorf M, Viazov S: Recombinant virus-like particles as a carrier of B- and T-cell epitopes of hepatitis $\mathrm{C}$ virus (HCV). Vaccine 2006;24:4369-4377.

296 Sominskaya I, Skrastina D, Dislers A, Vasiljev D, Mihailova M, Ose V, Dreilina D, Pumpens P: Construction and immunological evaluation of multivalent hepatitis B virus (HBV) core virus-like particles carrying HBV and HCV epitopes. Clin Vaccine Immunol 2010;17:1027-1033.

297 Yin Y, Zhang J, Dong D, Liu S, Guo Q, Song X, Li G, Fu L, Xu J, Chen W: Chimeric hepatitis $B$ virus core particles carrying an epitope of anthrax protective antigen induce protective immunity against Bacillus anthracis. Vaccine 2008;26:5814-5821.
298 Guan Q, Ma Y, Hillman CL, Ma A, Zhou G, Qing G, Peng Z: Development of recombinant vaccines against IL-12/IL-23 p40 and in vivo evaluation of their effects in the downregulation of intestinal inflammation in murine colitis. Vaccine 2009;27:7096-7104.

299 Yin Y, Li H, Wu S, Dong D, Zhang J, Fu L, $\mathrm{Xu}$ J, Chen W: Hepatitis B virus core particles displaying Mycobacterium tuberculosis antigen ESAT-6 enhance ESAT-6-specific immune responses. Vaccine 2011;29:56455651.

300 Neirynck S, Deroo T, Saelens X, Vanlandschoot P, Jou WM, Fiers W: A universal influenza A vaccine based on the extracellular domain of the M2 protein. Nat Med 1999;5: 1157-1163.

301 Jegerlehner A, Schmitz N, Storni T, Bachmann MF: Influenza A vaccine based on the extracellular domain of M2: weak protection mediated via antibody-dependent NK cell activity. J Immunol 2004;172:5598-5605.

302 De Filette M, Martens W, Smet A, Schotsaert M, Birkett A, Londoño-Arcila P, Fiers W, Saelens X: Universal influenza A M2e-HBc vaccine protects against disease even in the presence of pre-existing anti-HBc antibodies. Vaccine 2008;26:6503-6507.

303 Fiers W, De Filette M, El Bakkouri K, Schepens B, Roose K, Schotsaert M, Birkett A, Saelens X: M2e-based universal influenza A vaccine. Vaccine 2009;27:6280-6283.

304 Ravin NV, Kotlyarov RY, Mardanova ES, Kuprianov VV, Migunov AI, Stepanova LA, Tsybalova LM, Kiselev OI, Skryabin KG: Plant-produced recombinant influenza vaccine based on virus-like $\mathrm{HBc}$ particles carrying an extracellular domain of M2 protein. Biochemistry (Mosc) 2012;77:33-40.

305 Schödel F, Wirtz R, Peterson D, Hughes J, Warren R, Sadoff J, Milich D: Immunity to malaria elicited by hybrid hepatitis $\mathrm{B}$ virus core particles carrying circumsporozoite protein epitopes. J Exp Med 1994;180:10371046.

306 Sallberg M, Hughes J, Jones J, Phillips TR, Milich DR: A malaria vaccine candidate based on a hepatitis B virus core platform. Intervirology 2002;45:350-361.

307 Nardin EH, Oliveira GA, Calvo-Calle JM, Wetzel K, Maier C, Birkett AJ, Sarpotdar P, Corado ML, Thornton GB, Schmidt A: Phase I testing of a malaria vaccine composed of hepatitis B virus core particles expressing Plasmodium falciparum circumsporozoite epitopes. Infect Immun 2004;72: 6519-6527.

308 Nassal M, Skamel C, Kratz PA, Wallich R, Stehle T, Simon MM: A fusion product of the complete Borrelia burgdorferi outer surface protein A (OspA) and the hepatitis B virus capsid protein is highly immunogenic and induces protective immunity similar to that seen with an effective lipidated OspA vaccine formula. Eur J Immunol 2005;35: 655-665. 
-309 Skamel C, Ploss M, Böttcher B, Stehle T, Wallich R, Simon MM, Nassal M: Hepatitis $\mathrm{B}$ virus capsid-like particles can display the complete, dimeric outer surface protein $\mathrm{C}$ and stimulate production of protective antibody responses against Borrelia burgdorferi infection. J Biol Chem 2006;281:1747417481.

-310 Nassal M, Skamel C, Vogel M, Kratz PA, Stehle T, Wallich R, Simon MM: Development of hepatitis $B$ virus capsids into a whole-chain protein antigen display platform: new particulate Lyme disease vaccines. Int J Med Microbiol 2008;298:135142.

-311 Boulter N, Brown D, Wilkie G, Williamson S, Kirvar E, Knight P, Glass E, Campbell J, Morzaria S, Nene V, Musoke A, d'Oliveira C, Gubbels MJ, Jongejan F, Hall R: Evaluation of recombinant sporozoite antigen SPAG- 1 as a vaccine candidate against Theileria annulata by the use of different delivery systems. Trop Med Int Health 1999;4:A71A77.

- 312 Wang YS, Ouyang W, Liu XJ, He KW, Yu SQ, Zhang HB, Fan HJ, Lu CP: Virus-like particles of hepatitis $\mathrm{B}$ virus core protein containing five mimotopes of infectious bursal disease virus (IBDV) protect chickens against IBDV. Vaccine 2012;30:2125-2130.

- 313 Ranka R, Petrovskis I, Sominskaya I, Bogans J, Bruvere R, Akopjana I, Ose V, Timofejeva I, Brangulis K, Pumpens P, Baumanis V: Fibronectin binding nanoparticles for intracellular targeting addressed by $B$. burgdorferi BBK32 protein fragments. Nanomedicine 2012, E-pub ahead of print.

314 Engerix B: Summary for basis of approval. FDA, 1988. http://www.fda.gov/downloads/ BiologicsBloodVaccines/Vaccines/ApprovedProducts/UCM110155.pdf.

315 Recombivax HB: Summary for basis of approval. FDA, 1987. http://www.fda.gov/ downloads/BiologicsBloodVaccines/Vaccines/ApprovedProducts/UCM244544.pdf.

-316 Cooper C, Mackie D: Hepatitis B surface antigen-1018 ISS adjuvant-containing vaccine: a review of HEPLISAV ${ }^{\mathrm{TM}}$ safety and efficacy. Expert Rev Vaccines 2011;10:417-427.

\$17 Kapusta J, Modelska A, Figlerowicz M, Pniewski T, Letellier M, Lisowa O, Yusibov V, Koprowski H, Plucienniczak A, Legocki $\mathrm{AB}$ : A plant-derived edible vaccine against hepatitis B virus. FASEB J 1999;13:17961799.

-318 Richter LJ, Thanavala Y, Arntzen CJ, Mason HS: Production of hepatitis B surface antigen in transgenic plants for oral immunization. Nat Biotechnol 2000;18:1167-1171.

-319 Thanavala Y, Mahoney M, Pal S, Scott A, Richter L, Natarajan N, Goodwin P, Arntzen CJ, Mason HS: Immunogenicity in humans of an edible vaccine for hepatitis B. Proc Natl Acad Sci USA 2005;102:3378-3382.

- 320 Hayden CA, Streatfield SJ, Lamphear BJ, Fake GM, Keener TK, Walker JH, Clements JD, Turner DD, Tizard IR, Howard JA: Bio- encapsulation of the hepatitis B surface antigen and its use as an effective oral immunogen. Vaccine 2012;30:2937-2942.

321 Senturk H, Tabak F, Akdogan M, Erdem L, Mert A, Ozaras R, Sander E, Ozbay G, Badur $S$ : Therapeutic vaccination in chronic hepatitis B. J Gastroenterol Hepatol 2002;17:72-76.

- 322 Senturk H, Tabak F, Ozaras R, Erdem L, Canbakan B, Mert A, Yurdakul I: Efficacy of pre-S-containing HBV vaccine combined with lamivudine in the treatment of chronic HBV infection. Dig Dis Sci 2009;54:20262030.

323 Weinstein T, Chagnac A, Boaz M, Ori Y, Herman M, Zevin D, Schmilovitz-Weiss H, Gafter $\mathrm{U}$ : Improved immunogenicity of a novel third-generation recombinant hepatitis B vaccine in patients with end-stage renal disease. Nephron Clin Pract 2004;97:c67-c72.

324 Page M, Jones CD, Bailey C: A novel, recombinant triple antigen hepatitis $\mathrm{B}$ vaccine (Hepacare). Intervirology 2001;44:88-97.

325 Schlienger K, Montefiori DC, Mancini M, Rivière Y, Tiollais P, Michel ML: Vaccineinduced neutralizing antibodies directed in part to the simian immunodeficiency virus (SIV) V2 domain were unable to protect rhesus monkeys from SIV experimental challenge. J Virol 1994;68:6578-6588.

326 Michel M, Lone YC, Centlivre M, Roux P, Wain-Hobson S, Sala M: Optimisation of secretion of recombinant HBsAg virus-like particles: impact on the development of HIV-1/HBV bivalent vaccines. Vaccine 2007;25:1901-1911.

- 327 Eckhart L, Raffelsberger W, Ferko B, Klima A, Purtscher M, Katinger H, Rüker F: Immunogenic presentation of a conserved gp41 epitope of human immunodeficiency virus type 1 on recombinant surface antigen of hepatitis B virus. J Gen Virol 1996;77: 2001-2008.

328 Shchelkunov SN, Salyaev RK, Pozdnyakov SG, Rekoslavskaya NI, Nesterov AE, Ryzhova TS, Sumtsova VM, Pakova NV, Mishutina UO, Kopytina TV, Hammond RW: Immunogenicity of a novel, bivalent, plantbased oral vaccine against hepatitis $B$ and human immunodeficiency viruses. Biotechnol Lett 2006;28:959-967.

329 Li HZ, Gang HY, Sun QM, Liu X, Ma YB, Sun MS, Dai CB: Production in Pichia pastoris and characterization of genetic engineered chimeric HBV/HEV virus-like particles. Chin Med Sci J 2004;19:78-83.

-330 Bisht H, Chugh DA, Swaminathan S, Khanna N: Expression and purification of Dengue virus type 2 envelope protein as a fusion with hepatitis B surface antigen in Pichia pastoris. Protein Expr Purif 2001;23:84-96.

331 Lee IH, Kim CH, Ryu WS: Presentation of the hydrophilic domains of hepatitis $\mathrm{C}$ viral E2 envelope glycoprotein on hepatitis B surface antigen particles. J Med Virol 1996;50: 145-151.

332 Cheong WS, Drummer HE, Netter HJ: Delivery of a foreign epitope by sharing amino acid residues with the carrier matrix. J Virol Methods 2009; 158:35-40.

-333 Cheong WS, Reiseger J, Turner SJ, Boyd R, Netter HJ: Chimeric virus-like particles for the delivery of an inserted conserved influenza A-specific CTL epitope. Antiviral Res 2009;81:113-122.

334 Kotiw M, Johnson M, Pandey M, Fry S, Hazell SL, Netter HJ, Good MF, Olive C: Immunological response to parenteral vaccination with recombinant hepatitis B virus surface antigen virus-like particles expressing Helicobacter pylori KatA epitopes in a murine $H$. pylori challenge model. Clin Vaccine Immunol 2012;19:268-276.

335 Ameiss K, Ashraf S, Kong W, Pekosz A, Wu WH, Milich D, Billaud JN, Curtiss R 3rd: Delivery of woodchuck hepatitis virus-like particle presented influenza M2e by recombinant attenuated Salmonella displaying a delayed lysis phenotype. Vaccine 2010;28: 6704-6713.

336 Ohtaki N, Takahashi H, Kaneko K, Gomi Y, Ishikawa T, Higashi Y, Kurata T, Sata T, Kojima A: Immunogenicity and efficacy of two types of West Nile virus-like particles different in size and maturation as a second-generation vaccine candidate. Vaccine 2010;28: 6588-6596.

337 Zhang S, Liang M, Gu W, Li C, Miao F, Wang X, Jin C, Zhang L, Zhang F, Zhang Q, Jiang L, Li M, Li D: Vaccination with dengue virus-like particles induces humoral and cellular immune responses in mice. Virol J 2011;8:333.

338 Liu W, Jiang H, Zhou J, Yang X, Tang Y, Fang D, Jiang L: Recombinant dengue viruslike particles from Pichia pastoris: efficient production and immunological properties. Virus Genes 2010;40:53-59.

339 Lazo L, Hermida L, Zulueta A, Sánchez J, López C, Silva R, Guillén G, Guzmán MG: A recombinant capsid protein from Dengue-2 induces protection in mice against homologous virus. Vaccine 2007;25:1064-1070.

340 Lazo L, Gil L, Lopez C, Valdes I, Marcos E, Alvarez M, Blanco A, Romero Y, Falcon V, Guzmán MG, Guillén G, Hermida L: Nucleocapsid-like particles of dengue- 2 virus enhance the immune response against a recombinant protein of dengue-4 virus. Arch Virol 2010;155:1587-1595.

341 Baumert TF, Ito S, Wong DT, Liang TJ: Hepatitis $\mathrm{C}$ virus structural proteins assemble into virus-like particles in insect cells. J Virol 1998;72:3827-3836.

342 Lechmann M, Murata K, Satoi J, Vergalla J, Baumert TF, Liang TJ: Hepatitis C virus-like particles induce virus-specific humoral and cellular immune responses in mice. Hepatology 2001;34:417-423.

- 343 Elmowalid GA, Qiao M, Jeong SH, Borg BB, Baumert TF, Sapp RK, Hu Z, Murthy K, Liang TJ: Immunization with hepatitis $\mathrm{C}$ virus-like particles results in control of hepatitis $C$ virus infection in chimpanzees. Proc Natl Acad Sci USA 2007;104:8427-8432. 
-344 Falcón V, García C, de la Rosa MC, Menéndez I, Seoane J, Grillo JM: Ultrastructural and immunocytochemical evidences of core-particle formation in the methylotrophic Pichia pastoris yeast when expressing HCV structural proteins (core-E1). Tissue Cell 1999;31:117-125.

345 Acosta-Rivero N, Rodriguez A, Musacchio A, Falcón V, Suarez VM, Martinez G, Guerra I, Paz-Lago D, Morera Y, de la Rosa MC, Morales-Grillo J, Dueñas-Carrera S: In vitro assembly into virus-like particles is an intrinsic quality of Pichia pastoris derived $\mathrm{HCV}$ core protein. Biochem Biophys Res Commun 2004;325:68-74.

-346 Kojima A, Yasuda A, Asanuma H, Ishikawa T, Takamizawa A, Yasui K, Kurata T: Stable high-producer cell clone expressing viruslike particles of the Japanese encephalitis virus e protein for a second-generation subunit vaccine. J Virol 2003;77:8745-8755.

-347 Yoshii K, Goto A, Kawakami K, Kariwa H, Takashima I: Construction and application of chimeric virus-like particles of tick-borne encephalitis virus and mosquito-borne Japanese encephalitis virus. J Gen Virol 2008;89: 200-211.

-348 Okamoto S, Yoshii H, Matsuura M, Kojima A, Ishikawa T, Akagi T, Akashi M, Takahashi M, Yamanishi K, Mori Y: Poly- $\gamma$ glutamic acid nanoparticles and aluminum adjuvant used as an adjuvant with a single dose of Japanese encephalitis virus-like particles provide effective protection from Japanese encephalitis virus. Clin Vaccine Immunol 2012;19:17-22.

- 349 Tellinghuisen TL, Hamburger AE, Fisher BR, Ostendorp R, Kuhn RJ: In vitro assembly of alphavirus cores by using nucleocapsid protein expressed in Escherichia coli. J Virol 1999;73:5309-5319.

350 Mukhopadhyay S, Chipman PR, Hong EM, Kuhn RJ, Rossmann MG: In vitro-assembled alphavirus core-like particles maintain a structure similar to that of nucleocapsid cores in mature virus. J Virol 2002;76: 11128-11132.

351 Cheng F, Mukhopadhyay S: Generating enveloped virus-like particles with in vitro assembled cores. Virology 2011;413:153-160.

-352 Goicochea NL, De M, Rotello VM, Mukhopadhyay S, Dragnea B: Core-like particles of an enveloped animal virus can self-assemble efficiently on artificial templates. Nano Lett 2007;7:2281-2290.

- 353 Akahata W, Yang ZY, Andersen H, Sun S, Holdaway HA, Kong WP, Lewis MG, Higgs S, Rossmann MG, Rao S, Nabel GJ: A viruslike particle vaccine for epidemic Chikungunya virus protects nonhuman primates against infection. Nat Med 2010;16:334-338.

-354 Metz SW, Feenstra F, Villoing S, van Hulten MC, van Lent JW, Koumans J, Vlak JM, Pijlman GP: Low temperature-dependent salmonid alphavirus glycoprotein processing and recombinant virus-like particle formation. PLoS One 2011;6:e25816.
355 Bai B, Hu Q, Hu H, Zhou P, Shi Z, Meng J, Lu B, Huang Y, Mao P, Wang H: Virus-like particles of SARS-like coronavirus formed by membrane proteins from different origins demonstrate stimulating activity in human dendritic cells. PLoS One 2008;3:e2685.

-356 Zhou ZR, Wang ML, Deng F, Li TX, Hu ZH, Wang HL: Production of CCHF virus-like particle by a baculovirus-insect cell expression system. Virol Sin 2011;26:338-346.

357 Habjan M, Penski N, Wagner V, Spiegel M, Overby AK, Kochs G, Huiskonen JT, Weber F: Efficient production of Rift Valley fever virus-like particles: the antiviral protein MxA can inhibit primary transcription of bunyaviruses. Virology 2009;385:400-408.

358 Li C, Liu F, Liang M, Zhang Q, Wang X, Wang T, Li J, Li D: Hantavirus-like particles generated in $\mathrm{CHO}$ cells induce specific immune responses in C57BL/6 mice. Vaccine 2010;28:4294-4300.

359 Tong T, Crooks ET, Osawa K, Binley JM: HIV-1 virus-like particles bearing pure env trimers expose neutralizing epitopes but occlude nonneutralizing epitopes. J Virol 2012; 86:3574-3587.

360 Visciano ML, Diomede L, Tagliamonte M, Tornesello ML, Asti V, Bomsel M, Buonaguro FM, Lopalco L, Buonaguro L: Generation of HIV-1 virus-like particles expressing different HIV-1 glycoproteins. Vaccine 2011;29:4903-4912.

361 Tobin GJ, Nagashima K, Gonda MA: Immunologic and ultrastructural characterization of HIV pseudovirions containing Gag and Env precursor proteins engineered in insect cells. Methods 1996;10:208-218.

362 Tagliamonte M, Visciano ML, Tornesello ML, De Stradis A, Buonaguro FM, Buonaguro L: HIV-Gag VLPs presenting trimeric HIV-1 gp140 spikes constitutively expressed in stable double transfected insect cell line. Vaccine 2011;29:4913-4922.

363 Rovinski B, Haynes JR, Cao SX, James O, Sia C, Zolla-Pazner S, Matthews TJ, Klein MH: Expression and characterization of genetically engineered human immunodeficiency virus-like particles containing modified envelope glycoproteins: implications for development of a cross-protective AIDS vaccine. J Virol 1992;66:4003-4012.

364 Deml L, Kratochwil G, Osterrieder N, Knüchel R, Wolf H, Wagner R: Increased incorporation of chimeric human immunodeficiency virus type 1 gp120 proteins into Pr55gag virus-like particles by an EpsteinBarr virus gp220/350-derived transmem-
brane domain. Virology 1997;235:10-25.

365 Osterrieder N, Wagner R, Brandmüller C, Schmidt P, Wolf H, Kaaden OR: Protection against EHV-1 challenge infection in the murine model after vaccination with various formulations of recombinant glycoprotein gp14 (gB). Virology 1995;208:500-510.

-366 Garnier L, Ravallec M, Blanchard P, Chaabihi H, Bossy JP, Devauchelle G, Jestin A, Cerutti M: Incorporation of pseudorabies virus
gD into human immunodeficiency virus type 1 Gag particles produced in baculovirus-infected cells. J Virol 1995;69:40604068.

367 Di Bonito P, Grasso F, Mochi S, Petrone L, Fanales-Belasio E, Mei A, Cesolini A, Laconi G, Conrad H, Bernhard H, Dembek CJ, Cosma A, Santini SM, Lapenta C, Donati S, Muratori $\mathrm{C}$, Giorgi $\mathrm{C}$, Federico $\mathrm{M}$ : Anti-tumor CD8+ T cell immunity elicited by HIV-1based virus-like particles incorporating HPV16 E7 protein. Virology 2009;395:45-55.

368 Wu X, Liu H, Xiao H, Kim J, Seshaiah P, Nat soulis G, Boeke JD, Hahn BH, Kappes JC: Targeting foreign proteins to human immunodeficiency virus particles via fusion with Vpr and Vpx. J Virol 1995;69:3389-3398.

369 Kaczmarczyk SJ, Sitaraman K, Young HA, Hughes SH, Chatterjee DK: Protein delivery using engineered virus-like particles. Proc Natl Acad Sci USA 2011;108:16998-17003.

370 Sistigu A, Bracci L, Valentini M, Proietti E, Bona R, Negri DR, Ciccaglione AR, Tritarelli E, Nisini R, Equestre M, Costantino A, Marcantonio C, Santini SM, Lapenta C, Donati S, Tataseo P, Miceli M, Cara A, Federico M: Strong CD8+ T cell antigenicity and immunogenicity of large foreign proteins incorporated in HIV-1 VLPs able to induce a Nef-dependent activation/maturation of dendritic cells. Vaccine 2011;29:3465-3475.

-371 Luo L, Li Y, Kang CY: Expression of gag precursor protein and secretion of virus-like gag particles of HIV-2 from recombinant baculovirus-infected insect cells. Virology 1990;179:874-880.

372 Luo L, Li Y, Cannon PM, Kim S, Kang CY: Chimeric gag-V3 virus-like particles of human immunodeficiency virus induce virusneutralizing antibodies. Proc Natl Acad Sci USA 1992;89:10527-10531.

373 Kang CY, Luo L, Wainberg MA, Li Y: Development of HIV/AIDS vaccine using chimeric gag-env virus-like particles. Biol Chem 1999;380:353-364.

374 Shen L, Mazzara GP, DiSciullo SO, Panicali DL, Letvin NL: Immunization with lentivirus-like particles elicits a potent SIV-specific recall cytotoxic T-lymphocyte response in rhesus monkeys. AIDS Res Hum Retroviruses 1993;9:129-132.

375 Yamshchikov GV, Ritter GD, Vey M, Compans RW: Assembly of SIV virus-like particles containing envelope proteins using a baculovirus expression system. Virology 1995;214:50-58.

376 Yao Q, Kuhlmann FM, Eller R, Compans RW, Chen C: Production and characterization of simian-human immunodeficiency virus-like particles. AIDS Res Hum Retroviruses 2000;16:227-236.

377 Zhang R, Zhang S, Li M, Chen C, Yao Q: Incorporation of CD40 ligand into SHIV virus-like particles (VLP) enhances SHIVVLP-induced dendritic cell activation and boosts immune responses against HIV. Vaccine 2010;28:5114-5127. 
-378 Deo VK, Tsuji Y, Yasuda T, Kato T, Sakamoto N, Suzuki H, Park EY: Expression of an RSV-gag virus-like particle in insect cell lines and silkworm larvae. J Virol Methods 2011;177:147-152.

379 Tsuji Y, Deo VK, Kato T, Park EY: Production of Rous sarcoma virus-like particles displaying human transmembrane protein in silkworm larvae and its application to ligand-receptor binding assay. J Biotechnol 2011;155:185-192.

380 Leb VM, Jahn-Schmid B, Kueng HJ, Schmetterer KG, Haiderer D, Neunkirchner A, Fischer GF, Hartl A, Thalhamer J, Steinberger P, Bohle B, Seed B, Pickl WF: Modulation of allergen-specific T-lymphocyte function by virus-like particles decorated with HLA class II molecules. J Allergy Clin Immunol 2009; 124:121-128.

-381 Nikles D, Bach P, Boller K, Merten CA, Montrasio F, Heppner FL, Aguzzi A, Cichutek K, Kalinke U, Buchholz CJ: Circumventing tolerance to the prion protein $(\mathrm{PrP})$ vaccination with $\mathrm{PrP}$-displaying retrovirusparticles induces humoral immune responses against the native form of cellular PrP. J Virol 2005;79:4033-4042.

-382 Bach P, Kamphuis E, Odermatt B, Sutter G, Buchholz CJ, Kalinke U: Vesicular stomatitis virus glycoprotein displaying retroviruslike particles induce a type I IFN receptordependent switch to neutralizing IgG antibodies. J Immunol 2007;178:5839-5847.

383 Kueng HJ, Leb VM, Haiderer D, Raposo G, Thery C, Derdak SV, Schmetterer KG, Neunkirchner A, Sillaber C, Seed B, Pickl WF: General strategy for decoration of enveloped viruses with functionally active lipid-modified cytokines. J Virol 2007;81: 8666-8676.

-384 Haynes JR, Dokken L, Wiley JA, Cawthon AG, Bigger J, Harmsen AG, Richardson C: Influenza-pseudotyped Gag virus-like particle vaccines provide broad protection against highly pathogenic avian influenza challenge. Vaccine 2009;27:530-541.
385 Ruiss R, Jochum S, Wanner G, Reisbach G, Hammerschmidt W, Zeidler R: A virus-like particle-based Epstein-Barr virus vaccine. J Virol 2011;85:13105-13113.

>386 Bright RA, Carter DM, Crevar CJ, Toapanta FR, Steckbeck JD, Cole KS, Kumar NM, Pushko P, Smith G, Tumpey TM, Ross TM: Cross-clade protective immune responses to influenza viruses with $\mathrm{H} 5 \mathrm{~N} 1 \mathrm{HA}$ and NA elicited by an influenza virus-like particle. PLoS One 2008;3:e1501.

387 Galarza JM, Latham T, Cupo A: Virus-like particle (VLP) vaccine conferred complete protection against a lethal influenza virus challenge. Viral Immunol 2005;18:244-251.

388 Kang SM, Pushko P, Bright RA, Smith G, Compans RW: Influenza virus-like particles as pandemic vaccines. Curr Top Microbiol Immunol 2009;333:269-289.

389 Mena I, Vivo A, Pérez E, Portela A: Rescue of a synthetic chloramphenicol acetyltransferase RNA into influenza virus-like particles obtained from recombinant plasmids. J Virol 1996;70:5016-5024.

390 Wang BZ, Gill HS, Kang SM, Wang L, Wang YC, Vassilieva EV, Compans RW: Enhanced influenza virus-like particle vaccines containing the extracellular domain of matrix protein 2 and a Toll-like receptor ligand. Clin Vaccine Immunol 2012;19:1119-1125.

391 Casabona JC, Levingston Macleod JM, Loureiro ME, Gomez GA, Lopez N: The RING domain and the $L 79$ residue of $Z$ protein are involved in both the rescue of nucleocapsids and the incorporation of glycoproteins into infectious chimeric arenavirus-like particles. J Virol 2009;83:7029-7039.

392 Walpita P, Barr J, Sherman M, Basler CF, Wang L: Vaccine potential of Nipah viruslike particles. PLoS One 2011;6:e18437.

393 Sugahara F, Uchiyama T, Watanabe H, Shimazu Y, Kuwayama M, Fujii Y, Kiyotani K, Adachi A, Kohno N, Yoshida T, Sakaguchi T: Paramyxovirus Sendai virus-like particle formation by expression of multiple viral proteins and acceleration of its release by C protein. Virology 2004;325:1-10.
394 Li M, Schmitt PT, Li Z, McCrory TS, He B, Schmitt AP: Mumps virus matrix, fusion, and nucleocapsid proteins cooperate for efficient production of virus-like particles. J Virol 2009;83:7261-7272.

395 Warfield KL, Swenson DL, Negley DL, Schmaljohn AL, Aman MJ, Bavari S: Marburg virus-like particles protect guinea pigs from lethal Marburg virus infection. Vaccine 2004;22:3495-3502.

396 Swenson DL, Warfield KL, Negley DL, Schmaljohn A, Aman MJ, Bavari S: Viruslike particles exhibit potential as a pan-filovirus vaccine for both Ebola and Marburg viral infections. Vaccine 2005;23:30333042.

397 Warfield KL, Aman MJ: Advances in viruslike particle vaccines for filoviruses. J Infect Dis 2011;204(suppl 3):S1053-S1059.

398 Warfield KL, Swenson DL, Olinger GG, Kalina WV, Aman MJ, Bavari S: Ebola viruslike particle-based vaccine protects nonhuman primates against lethal Ebola virus challenge. J Infect Dis 2007;196(suppl 2):S430-S437.

399 Ye L, Lin J, Sun Y, Bennouna S, Lo M, Wu Q, Bu Z, Pulendran B, Compans RW, Yang $\mathrm{C}$ : Ebola virus-like particles produced in insect cells exhibit dendritic cell stimulating activity and induce neutralizing antibodies. Virology 2006;351:260-270.

400 VIPERdb (VIrus Particle ExploreR). http:// viperdb.scripps.edu/.

401 Carrillo-Tripp M, Shepherd CM, Borelli IA, Venkataraman S, Lander G, Natarajan P, Johnson JE, Brooks CL 3rd, Reddy VS: VIPERdb2: an enhanced and web API enabled relational database for structural virology. Nucleic Acids Res 2009;37:D436D442.

402 Gilbert RJ, Beales L, Blond D, Simon MN, Lin BY, Chisari FV, Stuart DI, Rowlands DJ: Hepatitis B small surface antigen particles are octahedral. Proc Natl Acad Sci USA 2005;102:14783-14788. 